LBNL-59773

\title{
Quantifying the Effect of the Principal-Agent Problem on US Residential Energy Use
}

\author{
Scott Murtishaw and Jayant Sathaye \\ Energy Analysis Department \\ Environmental Energy Technologies Division \\ Ernest Orlando Lawrence Berkeley National Laboratory \\ University of California \\ Berkeley, California 94720
}

12 August 2006

This work was supported by the Office of Energy Efficiency and Renewable Energy, US Department of Energy and in part by the Climate Change Division, Environmental Protection Agency under Contract No.DE-AC03-76SF00098. 



\section{Summary}

\section{Introduction}

The International Energy Agency (IEA) organized this project to investigate the effects of market failures in the end-use of energy that may isolate some markets or portions thereof from energy price signals. Quantifying the amount of energy associated with market failures helps to demonstrate the significance of energy efficiency policies beyond price signals. The IEA organized an international team of researchers to assess the impact of market failures in their own countries. Five countries participated in the study: Australia, Japan, the Netherlands, Norway, and the U.S. This paper describes the methodology and results of the U.S. team's study on energy efficiency barriers in the residential sector. The IEA will assemble the results of each country's findings and publish them together with some comparative analysis in a forthcoming volume.

This US study quantifies the extent that one type of market failure, the principal agent (PA) problem, affects energy use in the U.S. residential market. A PA problem arises in many spheres of economic activity, when one person, the agent, performs tasks on behalf of another person, the principal, but the agent performs the expected tasks in a way contrary to the principal's best interests. In residential energy use, this commonly occurs between home builders and prospective buyers, and renters and landlords (Jaffe and Stavins, 1994a). Home builders may have difficulty conveying the benefits of energy efficiency technologies to prospective buyers because these technologies and their future energy use consequences are not observable. Likewise, landlords may not be able to recover all of the value of such investments in the form of higher rents, where renters pay fuel bills, and tenants who make these investments in cases where the landlord pays the energy bill may not be able to get reduced rents. Thus, the PA problem is a function of incentives, information asymmetry, and enforcement capacity.

\section{Purpose}

The purpose of this study is to quantify both the number of households affected by the principal-agent (PA) problem and the associated site and primary energy use for refrigerators, water heaters, space heating and lighting. These four were selected both on the basis of their shares of total residential energy use and the way their characteristics contribute to the number of households and the associated energy use affected by the PA problem. We also estimate the energy saving potential from overcoming the PA barriers for refrigerators and water heaters. The 
findings of this study provide a quantitative basis for supporting other forms of government interventions that complement price policy for increasing the penetration of cost-effective energy efficient products. Such interventions may include the provision of additional information, energy performance standards and labels, building codes, etc.

\section{Methodology and Findings}

We developed a simple matrix in order to classify households into those affected by PA problems for each of the four end uses. For any given device, determining the cases involving a PA problem may be conceptualized as a two-by-two table that classifies the device according to the user's ability to choose the device and the user's responsibility for paying associated energy costs. Table ES-1 depicts this matrix.

Table ES-1. Principal-Agent Classification of End Users for the Residential Sector

\begin{tabular}{l|l|l|}
\hline & Can Choose Device & Cannot Choose Device \\
\hline Direct Energy Payment & Case N: No Problem & Case E: Efficiency Problem \\
\hline Indirect Energy Payment ${ }^{\mathrm{a}}$ & Case B: Both Usage and Efficiency Problem & Case U: Usage Problem \\
\hline
\end{tabular}${ }^{\mathrm{a}}$ Occupants pay the energy costs, but not directly commensurate with energy use. This may take the form of utilities
included in rent or a separate, but flat, energy fee. Often, this is due to the presence of a master meter serving multiple
housing units although a significant number of individually metered units also have utilities included in rent
(Levinson and Niemann, 2004).
b There may also be an efficiency problem if three parties are involved: one who chooses the device, one who pays the
energy cost, and the end user.

This matrix was applied to a set of 2003 U.S. housing data obtained from the American Housing Survey of the U.S. Census (U.S. Census Bureau 2005a) and U.S. Census construction statistics (U.S. Census Bureau 2005b, 2005c). The households were allocated to each group on the basis of characteristics such as tenancy status (rented vs. occupant-owned), age, and inclusion of energy costs into flat or common fees. Distinctions were also made based on housing unit type (single-family residence vs. multifamily residence) because single-family residences generally use more energy due to their larger size and greater number of occupants. We found that for refrigerators 33\% of households are affected by PA problems, for water heaters $78 \%$ are affected, for main space heating 53\% are affected, and for lighting 5\% are affected.

Once we determined the affected number of households by unit type, we used data on the average energy consumption for each end use from the 2001 Residential Energy Consumption Survey (U.S. EIA 2004a) to estimate the amount of energy used by the affected households. Table ES-2 summarizes these estimates and shows them as shares of the site energy consumed by that end use, total residential site energy, and total residential primary energy. Table ES-2 shows that an estimated 35\% of all residential site energy is associated with households affected by PA 
problems from these four end uses. The share would be larger if air conditioning and other end uses had been included in the study.

Table ES-2. Residential Energy Use Associated with the Principal-Agent Problem

\begin{tabular}{|l|r|r|r|r|r|}
\hline & $\begin{array}{c}\text { Refrigera } \\
\text { tors }\end{array}$ & $\begin{array}{c}\text { Water } \\
\text { Heating }\end{array}$ & $\begin{array}{c}\text { Space } \\
\text { Heating }\end{array}$ & \multicolumn{1}{c|}{ Lighting } & \multicolumn{1}{c|}{$\begin{array}{r}\text { Total, } \\
\text { TBtu }\end{array}$} \\
\hline Site Energy by End Use, TBtu (PJ) & $532(562)$ & $1,680(1,650)$ & $4,657(4,465)$ & $343(360)$ & 7,212 \\
\hline Associated Energy and Shares: & & & & & \\
Site Energy, TBtu (PJ) & $134(141)$ & $1,111(1,076)$ & $2,210(2,143)$ & $7.8(8.2)$ & 3,463 \\
$\quad$ Share of Site Energy Use & $25.2 \%$ & $66.1 \%$ & $47.5 \%$ & $2.3 \%$ & $48.0 \%$ \\
$\quad$ Share of Total Residential Site ${ }^{\text {a }}$ & $1.4 \%$ & $11.3 \%$ & $22.4 \%$ & $0.1 \%$ & $35.1 \%$ \\
\hline Primary Energy by End Use, TBtu (PJ) & $1,560(1,156)$ & $2,390(2,320)$ & $5,375(5,313)$ & $1,007(1,002)$ & 10,332 \\
\hline Associated Energy and Shares: & & & & & \\
Primary Energy, TBtu (PJ) & $394(392)$ & $1,561(1,519)$ & $2,570(2,490)$ & $23(23)$ & 4,548 \\
$\quad$ Share of Primary Energy Use & $25.2 \%$ & $65.4 \%$ & $47.8 \%$ & $2.3 \%$ & $44.0 \%$ \\
$\quad$ Share of Total Residential Primary ${ }^{\text {b }}$ & $2.2 \%$ & $8.9 \%$ & $14.6 \%$ & $0.1 \%$ & $25.8 \%$ \\
\hline Estimated Primary Annual Energy & & & N/A & N/A & 6.37 \\
Savings Based on 2003 Sales & $0.48(0.50)$ & $5.89(5.69)$ & &
\end{tabular}

Note: Above results are based on 2001 energy use as applied to 2003 household shares. Annual energy savings are for 2003 sales.

${ }^{\text {a }}$ Residential total site energy - 9,860 trillion Btu (9,840 PJ)

${ }^{\mathrm{b}}$ Residential total primary energy - 17, 600 trillion Btu (17,100 PJ)

In addition to calculating the associated energy use for the four end uses covered in this study, we also estimated potential annual energy savings from eliminating the PA problem for two of the end uses: refrigerators and water heaters. This calculation was performed for only one year's worth of sales of these products using data on 2003 shipments. We found that primary energy savings from overcoming the PA barriers affecting the sales of year 2003 refrigerators and water heaters could save nearly 6.4 TBtu per year.

\section{Conclusions}

We found that the available U.S. housing data was sufficient for the methodology we devised for allocating households to the various PA Cases, although there is some uncertainty with regard to the data on the number of households with utilities included in rent or other fees. Data from RECS 2001 enabled us to extend the allocation of households to a credible estimate of the annual energy consumption associated with PA problems. This approach may not be feasible for countries that do not maintain a similar degree of housing and energy consumption data.

Our research has revealed a couple of important findings: (1) price signals alone may have a limited effect on inducing energy conservation in the residential sector because a large share of energy is consumed by end users who either have little or no control over the efficiency of energy-using equipment (Case E) or who are shielded to some extent from the costs of their energy consumption (Cases B and $\mathrm{U}$ ). For similar reasons we believe that information-oriented 
programs alone are not likely to stimulate much savings for a large share of residential energy consumption.

Our study highlights the need for several key areas of future research. The key areas include: (1) completion of the estimation of energy savings from space heating, and (2) the estimation of costs associated with the PA problem for the analyzed end uses. The above work could be expanded to include equipment such as set top boxes and other electronic equipment whose energy share and saturation are increasing rapidly and are not yet subject to non-price government intervention. Another fruitful set of analysis could focus on the end uses in the commercial buildings sector where parallel data sets are available, and in the industrial sector where organizational barriers have been documented as a significant impediment to price signals. 


\begin{abstract}
The International Energy Agency (IEA) initiated and coordinated this project to investigate the effects of market failures in the end-use of energy that may isolate some markets or portions thereof from energy price signals in five member countries. Quantifying the amount of energy associated with market failures helps to demonstrate the significance of energy efficiency policies beyond price signals. In this report we investigate the magnitude of the principal-agent (PA) problem affecting four of the major energy end uses in the U.S. residential sector: refrigeration, water heating, space heating, and lighting. Using data from the American Housing Survey, we develop a novel approach to classifying households into a PA matrix for each end use. End use energy values differentiated by housing unit type from the Residential Energy Consumption Survey were used to estimate the final and primary energy use associated with the PA problem. We find that the 2003 associated site energy use from these four end uses totaled over 3,400 trillion Btu, equal to $35 \%$ of the site energy consumed by the residential sector.
\end{abstract}




\section{$1 \quad$ Introduction}

The International Energy Agency (IEA) organized this project to investigate the effects of market failures in the end-use of energy that may isolate some markets or portions thereof from energy price signals. While there is a general presumption among economists that markets respond efficiently to price signals, there is also substantial evidence that at least for some markets and end uses market failures exist that limit the effect of price signals. The result is that energy usage in these markets persists at levels higher than economic theory would otherwise suggest. Five countries participated in the study: Australia, Japan, the Netherlands, Norway, and the U.S. This paper describes the methodology and results of the U.S. team's study of four major end uses/products (refrigerators, water heaters, main space heaters, and lighting) in the residential sector. Other studies evaluated vending machines and leased office spaces in Japan; organizational decision making in industrial firms, residential water heaters, leased office space,

and standby power in homes in Norway; leased cars, standby power consumption, and space heating in rental housing in The Netherlands; and organizational decision making in industrial firms in Australia. The IEA will assemble the results of each country's findings and publish them together with some comparative analysis in a forthcoming volume.

The purpose of this study is to quantify both the number of households affected by one type of market failure, the principal-agent (PA) problem, and the site and primary energy use associated with these affected households for the four end uses listed above. These four were selected both on the basis of their shares of total residential energy use and the differences in their characteristics that highlight different factors contributing to the number of households and the associated energy use affected by the PA problem. We also estimate the energy saving potential from overcoming the PA barriers for refrigerators and water heaters. The findings of this study provide a quantitative basis for supporting other forms of government intervention that complements price policy for the penetration of cost-effective energy efficient products. Such intervention may include the provision of additional information, energy performance standards and labels, building codes, etc.

\subsection{Principal-Agent Problem}

Many barriers to energy efficiency have been identified in the energy policy literature since the question of barriers to financially attractive investments in energy efficiency first began to receive significant attention in the 1970s and 1980s. Previous studies have focused largely on explaining why under-investments in energy efficiency are widespread, identifying the specific 
barriers responsible, and attempting to quantify the technical, economic (perfect markets), and market (actual conditions) scenarios for potential energy savings. Jaffe and Stavins (1994) and Sathaye et al. (2001) provide a classification of the many barriers and the corresponding energy saving potential. They classify the types of barriers that could constitute market failures. These include the principal-agent and lack of information problems.

Multiple barriers have been defined in these previous studies, but few studies have attempted to quantify the "excess" energy consumed due to any particular barrier or the savings potential from mitigating it. One study by Brown (1993) showed the extent to which the cost of conserved energy curve is changed when barriers are explicitly included in the estimation of the potential for US residential energy savings. At the same cost of conserved energy, Brown estimated that inclusion of barriers would halve the potential energy savings. Sathaye and Murtishaw (2004) demonstrate the effects of lack of information and other barriers in explaining the difference between actual and estimated market penetration of energy efficient lighting in California that is apparently cost-effective. In this assessment, they note the difficulties in quantifying the share of different barriers in reducing estimated penetration.

Based on the above experience, this study focused on the PA problem because quantifying its extent and the excess energy consumption it causes was thought to be more tractable than for other market failures. Cases where PA problems exist can be identified based on where multiple parties are involved with buying energy-consuming devices, using those devices, and paying the associated energy costs. To the extent that differences in energy consumption can be quantified between PA affected and non-PA affected households, controlling for other factors, the effect of the PA barrier can be quantified.

Bannock et al. (1992) provide a broad definition of the PA problem as:

The [PA] problem arises in many spheres of economic activity, when one person, the principal, hires an agent to perform tasks on his behalf but cannot ensure that the agent performs them in exactly the way the principal would like. The efforts of the agent are impossible or expensive to monitor and the incentives of the agent differ from those of the principal.

Note that there are several components to this definition: 1) the agent's actions can incur some cost or disutility for the principal, 2) the incentives of the principal and the agent are misaligned, and 3) it is difficult or impossible for the principal to monitor (or constrain) the actions of the agent. The inability of the principal to monitor the agent's actions (or perhaps to 
assess the costs of those actions) is generally linked to presence of asymmetric information between the principal and the agent.

It has long been recognized that the PA problem is pervasive in the rental market (for which the PA problem has been referred to as the landlord-tenant barrier) where landlords will generally not purchase efficient devices for rental properties since the tenants pay the cost of operating the devices (Jaffe and Stavins, 1994). This phenomenon has also been studied in the new home market where builders do not optimize home energy efficiency in order to hold construction costs down.

In the residential sector, the conceptualization of principal and agent must be stretched beyond a strictly literal definition. For example, PA problems often exist between renters and landlords. The renter pays the landlord/agent for the use of the apartment and any included furniture and appliances. The renter does not specifically request the landlord to choose the appliances. Indeed, any included appliances are usually already in place. The "principal” is really the whole set of possible renters. These principals may prefer to have efficient appliances that produce lower utility costs, but their agents, the landlords, are more concerned with initial costs since they do not incur the expense of running the appliances. ${ }^{1}$

As described above, the PA problem is actually a function of several different conditions. Central to the PA problem is the status of information related to equipment performance. The quality and extent of information may be thought to lie along a spectrum. At one end there is no information. Even the equipment manufacturers may not know the expected annual energy consumption of their devices. Without any performance information, there is no way to determine the extent, or existence, of inefficient energy consumption. In this case, research is necessary to assess the annual energy consumption of the available models under expected operating conditions, and hence there are no market barriers to technology penetration.

At the next stage, manufacturers may have determined the efficiency of their products but are not required to provide the information on efficiency labels. Neither the landlord nor the tenant has enough information to know how the equipment will perform. In this case, one cannot say that there is a PA problem because the agent cannot know whether she is acting in the principal's interests or not. In the middle of the spectrum, information is available, but its

\footnotetext{
${ }^{1}$ The PA barrier may also manifest in other ways that affect efficiency. One way concerns the fuel choices selected for end uses such as main space heating and water heating. For example, developers may choose to install electric space heating to lower building costs even though for tenants, electric space heating is more expensive than gas heating in most instances and uses more primary energy. Another effect concerns routine maintenance. Landlords may not maintain devices well when tenants pay the operating costs. We have not attempted to quantify these PA effects in this study.
} 
distribution is asymmetric. The landlord has the opportunity to inspect efficiency labels before purchase, but then he can remove the labels before installing them in his rental units. An unscrupulous landlord could claim that the appliances are particularly efficient even when they are not. At the other end of the spectrum, both principal and agent have adequate information to know whether the equipment is the best choice.

Even with perfect information the incapacity of the principal to control the agent's actions may still produce a PA problem. A fully informed tenant cannot force a landlord to buy a more efficient end use device. Thus, the PA problem is a function of incentives, information asymmetry, and enforcement capacity.

This study focuses on isolating the extent of the PA problem. Inefficiencies arising from barriers to energy efficiency that are primarily related to lack of information, or the inability to process it, are not included. Generally, information barriers are predominant when an occupant has the ability to choose the devices he or she will use and either no performance information is available, or it is available but the occupant fails to purchase a comparable, more energy efficient model.

\subsection{Policy Background in the U.S.}

In the wake of the 1973 oil crisis, energy conservation and energy efficiency began to receive serious attention as a complement to energy supply to meet energy demands. Government agencies at all levels initiated research into the underlying causes of "excess" energy consumption, i.e. the extra energy consumed due to underinvestment in cost-saving energy efficiency investments. This came to be known as the energy paradox - the persistent presence of widespread inefficiency in energy end use devices where comparable energy efficient options were available (Shama, 1983; Jaffe and Stavins, 1994a; Jaffe and Stavins 1994b).

In order to explain this paradox, researchers began to explore the question of "barriers" to energy efficiency that might inhibit firms or consumers from making what appeared to be attractive investments in efficiency. A vigorous debate ensued regarding the delineation of these barriers, whether any of these barriers constitute true market failures, and the extent to which these barriers contribute to a reduction in consumer utility. (See for example, Energy Policy 22 (10), the special issue on barriers to energy efficiency)

Although the causes and the magnitude of the problem were not fully understood, federal and state governments enacted legislation and established programs to save energy. Three basic types of approaches were used to increase adoption of more efficient options. Information and awareness campaigns were launched to encourage people to lower their thermostats, to install 
insulation, to drive less, to take public transit, etc. Various information campaigns were also targeted to industrial firms and to builders of residential and commercial structures. Many states began to require electric and gas utilities to undertake demand-side management (DSM) activities and offer rebates to customers for purchasing efficient products and making efficiency upgrades to their homes and businesses. Federal and state agencies also adopted energy performance standards for a wide variety of products and building codes to ensure that builders met certain requirements regarding insulation, and heating and cooling equipment.

Information-oriented programs, rebate programs and standards have together mitigated the extent of the PA problem. Our estimates of energy saving potential for refrigerators and water heaters (described below) would be much higher if not for the standards currently in place. However, their presence has not completely solved the PA problem and cannot as long as some cost-saving devices exist that are more efficient than the minimum standard.

\section{$2 \quad$ Methodology and Data}

\subsection{Methodology Applied to the Principal-Agent Problem in Energy End-Use}

The PA problem arises in two separate transactions in the end use of energy. The first transaction is between the seller and purchaser of the end use device, and the second one between the owner and user of the device. In the first transaction, the purchaser may not buy the most efficient device, and in the second case, the user may use the device wastefully, if he/she does not pay the fuel and/or electricity costs in a manner directly proportional to consumption. In either case, a problem arises since either the selection or use of the device is shielded from a utility price signal. The response to a price signal is then masked and delayed because it is felt through a higher cost of owning or renting a residence. ${ }^{2}$

In order to determine whether any particular end use is affected by the PA problem, three questions must be answered. First, who uses the device? Second, who selects the device? Third, who pays the energy cost? Theoretically, if the answer to these questions is not the same person or entity, a PA problem exists, albeit of two different types. If the person paying the utility bill is not the person using the device, the user may consume more energy services than if he were not shielded from the price of energy. Similarly, if the person paying for energy is not the person

\footnotetext{
${ }^{2}$ One reviewer noted that in cases where the PA problem is severe, there may be a lack of efficient models to choose from because there will be little demand for them. The reviewer pointed to apartment-sized refrigerators as one possible example. A review of the available Energy Star refrigerator models (Energy Star 2006) lists about eighty models in the 7 to 18 cubic foot range, but this amounts to only $6 \%$ of the Energy Star models greater than 7 cubic feet.
} 
choosing the device, the buyer will generally choose among the cheapest, and often least efficient, options. Thus, the PA problem can arise from two kinds of split incentives, one concerning usage (demand for energy services) and the other concerning the technical efficiency of the end-use device.

For any given device, determining the cases involving a PA problem may be conceptualized as a two-by-two table that classifies the device according to user's ability to choose the device and the user's responsibility for paying associated energy costs (Table 1).

There are two points to keep in mind about the PA classification matrix. One is that the numbers of households falling into each case depend on the end use. For example, an apartment dweller may not be able to choose her own water heater, but does choose her own television. Assuming she pays for her own energy usage, she would fall into Case $\mathrm{N}$ for televisions but Case E for water heaters. The second point is that the matrix describes a given set of households at one point in time. Housing units may move from one category to another over time. This often happens when a pre-installed device must be replaced. The homeowner may have had no choice when first buying the house but can choose the replacement unit when the original device fails. A housing unit can also move from one category to another if its tenancy status changes. This happens when a homeowner buys a new house and keeps possession of the first one to use as a rental property or when an apartment building is converted to condos.

In the residential sector, the user is the dwelling occupant. The box labeled "Case N" would generally be composed of households that are occupant-owned, e.g., single-family residences (SFRs) and condominiums. These residents generally choose their own appliances, furnaces, air conditioners, etc., although in new homes these items are often pre-installed and the residents cannot choose until the originals are replaced. Newer occupant-owned households are placed in Case E with respect to pre-installed appliances until those appliances are replaced. Case E households are mostly composed of individually billed rental households and new occupantowned houses for which the occupants did not select one or more energy-using appliances or features. Most occupants, whether owners or renters, pay their own utility bills, although a significant number of renters have some utilities included in their rent. This is less true of electricity than other fuels since most housing units are individually metered for electricity. These households fall into Case B and Case U. Most of these households are rental units, covered by Case U. The Case B units consist of a small number of condominiums where the cost of one or more fuels is included in a condo fee. 
Table 1. Principal-Agent Classification of End Users for the Residential Sector

\begin{tabular}{|c|c|c|}
\hline & Can Choose Device & Cannot Choose Device \\
\hline Direct Energy Payment & Case N: No Problem & Case E: Efficiency Problem \\
\hline Indirect Energy Payment $^{\mathrm{a}}$ & Case B: Usage and Efficiency Problem & Case U: Usage Problem \\
\hline
\end{tabular}

${ }^{a}$ Occupants pay the energy costs, but not directly commensurate with energy use. This may take the form of utilities included in rent or a separate, but flat, energy fee. Often, this is due to the presence of a master meter serving multiple housing units although a significant number of individually metered units also have utilities included in rent (Levinson and Niemann, 2004).

b There may also be an efficiency problem if three parties are involved: one who chooses the device, one who pays the energy cost, and the end user.

Note that in Case $\mathrm{N}$ and Case $\mathrm{B}$, when categorizing the occupants of a household as being able to choose their own devices, this line can be fuzzy. One illustrative case concerns water heaters. Water heaters are frequently replaced following a catastrophic failure. Since the water heater must be replaced urgently, homeowners generally call one or two plumbers and take whatever model that plumber happens to carry in stock. In a sense, a PA problem exists because the plumber could install a more efficient model to reduce the homeowner's long-term costs. However, a well-informed homeowner (or a patient one who doesn't mind going without hot water for a couple of days) can avoid being at the mercy of the plumber's water heater selection. A very conscientious homeowner may know that a water heater is nearing the end of its expected lifetime and do some prior research to be prepared the failure of his water heater. Thus, for purposes of this study, replacements of water heaters by occupant-owners are classified as a Case E PA problem for some households and as a Case $\mathrm{N}$ for others, based on an assumed rate of emergency replacements.

\subsection{Data Sources Used for the U.S. Residential Sector}

In order to quantify energy consumed by these four end uses that is affected by PA barriers, we used the most recent housing and end use energy consumption data available. The Census Bureau’s American Housing Survey 2003 (AHS 2003) (U.S. Census Bureau, 2005a) lists 105.8 million year-round occupied residences in 2003. Of these there were 74 million SFRs, 25 million multifamily residences (MFRs), and 6.9 million mobile homes. The housing type tends to be a strong determinant of energy consumption. In 2001, SFRs and mobile homes used almost twice as much energy per household as MFRs (U.S. EIA, 2004a). About 68\% of housing units in the U.S. are occupant-owned. In general, occupant-owned units tend to be SFRs or mobile homes (about 5\% of occupant-owned MFRs were condos), while 64\% of all rental units are MFRs.

Energy consumption data were taken from the Residential Energy Consumption Survey 2001 (RECS 2001) (U.S. EIA, 2004a). Since the years for housing data and energy consumption 
are not the same, what we have done in effect is use 2001 average efficiencies and energy consumption for 2003 households. In reality, 2003 average efficiencies were probably slightly lower than in 2001 and total energy consumption was probably higher, but we did not attempt to adjust for this difference because there were insufficient data. ${ }^{3}$ Interestingly, RECS 2001 lists slightly more occupied households, 107 million, than AHS 2003. This is perhaps due to sampling differences or the inclusion of some residences that are not inhabited year-round in the RECS 2001 data. Due to these reasons, the total energy consumption for some end uses may not equal the totals shown in RECS 2001.

According to RECS 2001, U.S. households used 9.86 quadrillion British thermal units (Btu) or 9.84 exajoules (EJ) of site energy. ${ }^{4}$ The distribution of site energy by end use is shown in Table 2. Space heating is by far the largest single end use of site energy, accounting for nearly half of all energy consumed in 2001. This study examines the nature and magnitude of the PA problem for four end uses: space heating, refrigerators, water heating, and lighting. Together, these end uses accounted for nearly $73 \%$ of residential site energy consumption.

Table 2. Site Energy Use, 2001

\begin{tabular}{|l|c|c|c|}
\hline \multicolumn{1}{|c|}{ End Use } & \multicolumn{3}{|c|}{ Site Energy } \\
\cline { 2 - 4 } & QBtu & QBtu Share & Exajoules \\
\hline Space Heating & 4.62 & $46.9 \%$ & 4.47 \\
Water Heating & 1.68 & $17.1 \%$ & 1.65 \\
Refrigerators & 0.53 & $5.4 \%$ & 0.56 \\
Lighting & 0.34 & $3.5 \%$ & 0.36 \\
Air Conditioning & 0.62 & $6.3 \%$ & 0.65 \\
Appliances \& Misc & 2.06 & $20.9 \%$ & 2.17 \\
\hline Total & 9.86 & $100 \%$ & 9.84 \\
\hline
\end{tabular}

Sources: U.S. EIA, 2004a and U.S. EIA, 2005

\section{$3 \quad$ Results}

\subsection{Description of Principal-Agent Calculations for Refrigerators}

With respect to Table 1, refrigerators present a special case since user behavior has little impact on energy consumption. For a given refrigerator, energy consumption is not responsive to

\footnotetext{
${ }^{3}$ We could have used 2003 data from the Annual Energy Review 2003 (U.S. EIA, 2004d), but the 2001 values given are not consistent with RECS 2001.

${ }^{4}$ One quadrillion $\left(10^{15}\right)$ Btu equals 1.055 exajoules $\left(10^{18}\right.$ joules). Because energy figures are given in gross calorific values (GCV) in the U.S. and net calorific values (NCV) in most other countries, a correction must be made to the reported energy data to make them comparable to the système international units used elsewhere. The GCV to NCV factors are 1 for electricity, 0.95 for liquid fuels, and 0.9 for natural gas. Coincidentally, with the final fuel mix reported in RECS 2001, the conversions balanced each other out to within $0.1 \%$.
} 
energy cost because household occupants do not use the refrigerator "more" as a consequence of not paying energy costs. As a result, for refrigerators the above classification simplifies into determining those cases where there is an efficiency problem. In Case $\mathrm{U}$, there is no PA problem because it is in landlords' interest to choose an efficient refrigerator given that they are paying the cost of electricity.

Figure 1 shows how the factors that determine whether a PA problem exists for a given household map to the various cases. Five major factors affect the final designation of the households into their respective cases: 1) whether the unit is a SFR or MFR; 2) whether it is occupant-owned or rented; 3) if occupant-owned, whether it was constructed in the last fifteen years (the approximate average lifespan of a refrigerator $)^{5}$; 4) if rented, whether the landlord provides the refrigerator or not; and 5) whether electricity is included in rent or other fees. These factors produce 12 types of households for the purposes of this analysis, which are represented by the end points in Figure 1.

Table 3 groups the households from Figure 1 by case. The table shows both the number of households falling into each case (with the percentage of the total in brackets) as well as the amount of site energy consumed annually, in trillion Btu (TBtu) and petajoules (PJ), by the refrigerators in these households. The percentages differ because there is a higher proportion of SFRs in Case N, and SFRs tend to have both larger refrigerators and a higher incidence of secondary refrigerators. Below we describe the steps taken to calculate the number of households falling into each case.

Table 3. Refrigerators Users by Number and Share of Households and Site Energy

\begin{tabular}{|c|c|c|}
\hline & Can Choose Device & Cannot Choose Device \\
\hline $\begin{array}{l}\text { Direct Energy } \\
\text { Payment }\end{array}$ & $\begin{array}{l}\text { Case N: } 70.8 \text { million households [67\%] } \\
382 \text { TBtu [72\%], } 403 \mathrm{PJ} \\
\text { Occupant-owned residences: } \\
\text { Most newer ones } \\
\text { Those older than } 15 \text { years }{ }^{\text {a }} \\
\text { Rental units: } \\
\text { Those with no refrigerator included }\end{array}$ & $\begin{array}{l}\text { Case E: } 30.4 \text { million households [29\%] } \\
134 \text { TBtu [25\%], } 141 \\
\text { Occupant-owned residences: Some } \\
\text { newer ones } \\
\text { Rental units: Most of these units }\end{array}$ \\
\hline $\begin{array}{l}\text { Indirect Energy } \\
\text { Payment }\end{array}$ & $\begin{array}{l}\text { Case B: } 0.3 \text { million households [0\%] } \\
0.90 \text { TBtu [0\%], 0.95 PJ } \\
\text { Condominiums: Small number } \\
\text { Rental units: Small number }\end{array}$ & $\begin{array}{l}\text { Case U: } 4.4 \text { million households [4\%] } \\
14.6 \text { TBtu [3\%], 15.4 PJ } \\
\text { Condominiums: Small number } \\
\text { Rental units: Significant number }\end{array}$ \\
\hline
\end{tabular}

${ }^{\mathrm{a}}$ Assumes original refrigerator has been replaced by owner.

${ }^{\mathrm{b}}$ For refrigerators, no efficiency problem exists assuming same agent (e.g. landlord) chooses the device and pays for energy. This may not be true in some newer buildings where electricity is included in rent if the developer selected refrigerators instead of the landlord.

\footnotetext{
${ }^{5}$ This matters since many newly completed residences have the refrigerator pre-installed. Even though the house or condo is built for occupant ownership, the purchaser may not be able to choose the refrigerator model. However, once the original refrigerator fails, the owner chooses the replacement refrigerator.
} 
Data used for these calculations came from four different sources. Data on number of refrigerators in the stock and energy consumption for refrigeration are from RECS (U.S. EIA, 2004a). Data on number of housing units by unit type, year of completion, and ownership status are from the AHS 2003. Statistics on whether utilities are included in rent are also taken from AHS. Figures on the number of single-family and multi-family housing units completed in 2003 with refrigerators pre-installed were provided by the National Association of Home Builders (NAHB, 2005). Data on refrigerator shipments and average shipment-weighted energy consumption were drawn from the Association of Home Appliance Manufacturers' 2003 Fact Book (AHAM, 2003).

\subsubsection{Case $N$}

While refrigerators are pre-installed in many new occupant-owned and rented units, when a refrigerator in an occupant-owned unit must be replaced, it is assumed that the occupant always has control over the model selected. Therefore an occupant-owned household with pre-installed appliances is affected by a PA problem when the unit is first purchased but ceases to be affected when the appliances are replaced. This necessitates splitting occupant-owned units into newer and older households depending on the average lifespan of the appliance in question. Since the average refrigerator lifetime is 15 years, occupant-owned units are split into two groups on this basis. 
Figure 1. Refrigerator Decision Tree for Allocating Households to Four Principal-Agent Cases, Million Housing Units

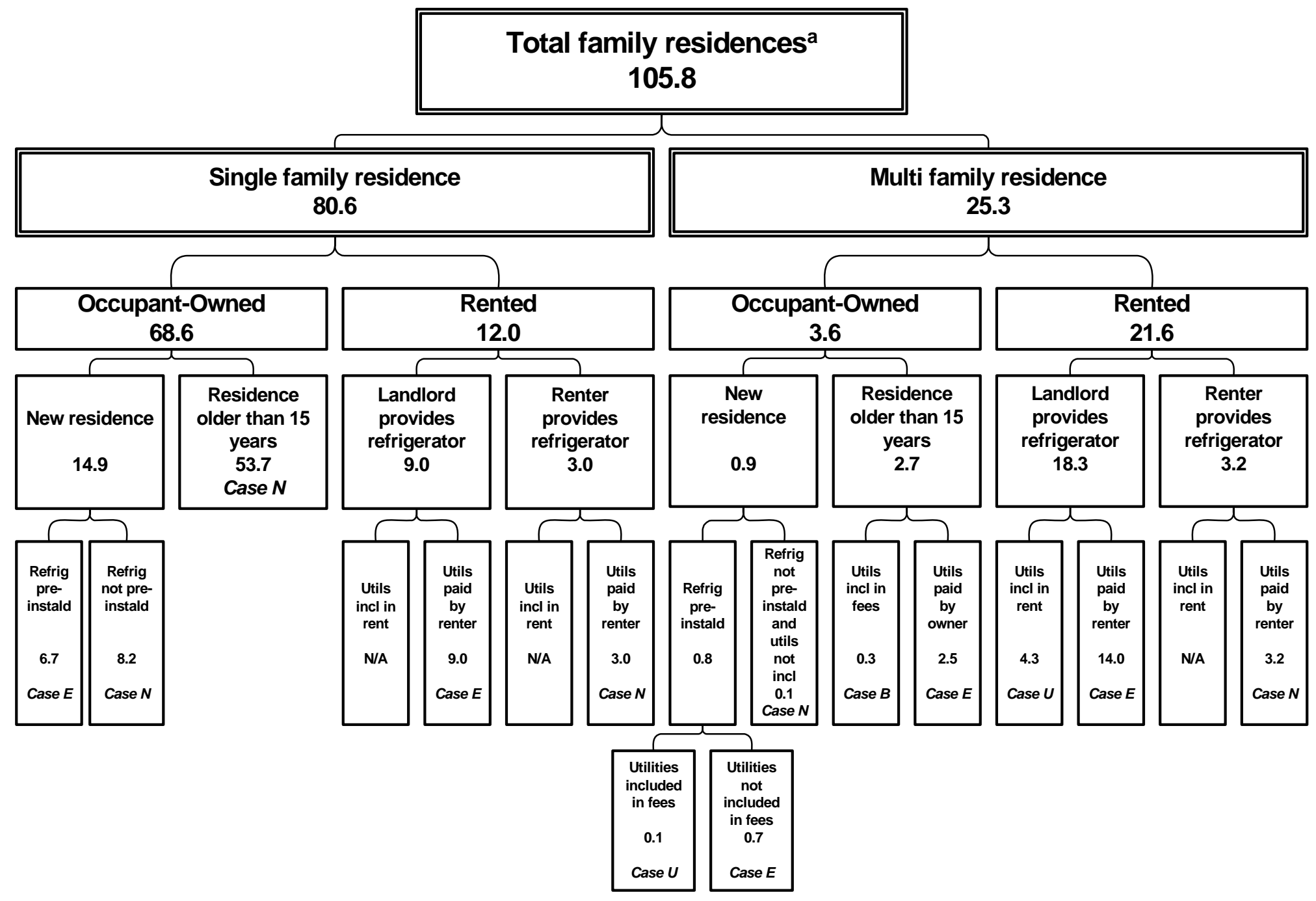

${ }^{a}$ Numbers in parent categories will not always equal the sum of subordinate categories due to rounding. 
To estimate the number of housing units falling in Case $\mathrm{N}$, we began with occupantowned SFRs. In newer units, the refrigerator is often pre-installed by the builder. According to NAHB, refrigerators were pre-installed by builders in 45\% of new SFR units. Interviews with a couple of builders in the northern California region lead us to believe that in many, if not most, cases the buyers are able to choose among a few different models selected by the builder, but we could find no national data on how often buyers are able to choose refrigerators and how often the models selected by builders include Energy Star options. In the absence of any data on the availability of Energy Star options, we assume that all $45 \%$ of the homes with pre-installed refrigerators are subject to PA problems, but in our sensitivity analysis (described in section 3.5) we assume that only half of the recently-built homes with pre-installed refrigerators are subject to the PA problem. The AHS provides figures on housing completions by use (owned vs. rental) for five-year increments. According to AHS, 15.7 million occupant-owned units have been built since 1990. About 95\% of the occupant-owned units in the housing stock are SFRs or mobile homes, so newer housing completions were apportioned into SFRs and MFRs on the same basis. Applying this share and the figures from NAHB results in 8.2 million newer occupant-owned SFRs, that is the $55 \%$ of new occupant-owned households where the occupants select the refrigerator.

The past fifteen years worth of occupant-owned housing completions were simply subtracted from the occupant-owned stock (with a slight adjustment for condominiums where electricity appears to be included in a condominium fee), resulting in 53.7 million SFRs where occupants have chosen a new refrigerator to replace an old one. We assume that SFR renters probably have the opportunity to choose their own refrigerators more often than MFR renters, so a higher percentage was used. Using a share of $25 \%$ of rental SFRs where renters supply their own refrigerators results in 3.0 million units.

For MFRs many of the same factors were considered. Using AHS figures we determined that roughly 0.9 million of the 3.6 million occupant-owned MFRs had been built in the last fifteen years. According to NAHB, 85\% of new MFRs have a pre-installed refrigerator so only 0.1 million occupant-owned MFR households fall into Case N. Taking the stock of older condos and subtracting out the number where utilities are included in rent adds another 2.5 million units to Case N. Finally, using the NAHB data, we assume that in the $15 \%$ of rental MFRs where the landlord does not provide the refrigerator, the utilities are never included in the rent. Thus, the entire population of 3.2 million MFR units with no refrigerator provided also belong in Case $\mathrm{N}$. In all, there are 70.8 million household in Case $\mathrm{N}$, most of which are SFRs. 
Several assumptions were made to calculate the numbers for Case N: 1) newer occupantowned units have the same SFR/MFR split as the existing occupant-owned stock, 2) occupants choose refrigerators in 25\% of rental SFRs (slightly more than in MFRs), 3) the percentage of new MFRs with refrigerators supplied in 2003 applies equally to all newer MFRs whether occupant-owned or rented and to older rented MFRs as well, and 4) the NAHB percentages of SFRs with refrigerators preinstalled for 2003 were used for all SFRs built since 1990.

\subsubsection{Case $E$}

Case E units consist of the $45 \%$ of new occupant-owned SFR units (6.7 million) where the refrigerator is pre-installed and the $75 \%$ of rental SFRs with the refrigerator included (9 million). In addition there are the $85 \%$ of new occupant-owned MFR units with a pre-installed refrigerator and occupant-paid electricity ( 0.7 million). Subtracting the units where the electricity is included in rent or other fees from the $85 \%$ of all rental MFR units that include a refrigerator leaves 14 million households. This produces a total of 30.4 million households in Case E.

\subsubsection{Case B}

For Case B, we assumed that in no case where the utilities are included in a rental unit does the household supply its own major appliances. However, according to AHS, in roughly 0.33 million occupant-owned MFRs electricity is included in a flat or combined fee. We split these into old and new units using the share of old units in the condominium stock (77\%). This accounts for the 0.25 million households in Case B. We also assumed that AHS figures on SFRs with electricity included in rent or other fees (most of which are occupant occupant-owned) are simply misreports. ${ }^{6}$

\subsubsection{Case $U$}

Case $\mathrm{U}$ consists of the 0.08 million newer condominium units where both the electricity and refrigerator are included (i.e., the remainder from Case B) as well as the 4.3 million rental MFR units that, according to AHS, have electricity included in rent or other fees. We assume in

all cases where utilities are included for rental MFRs, so is the refrigerator. Together with the households in Case N, this results in 75.1 million residences without a PA problem.

\footnotetext{
${ }^{6}$ The information on whether utilities are included in rent or other fees is given in response to a survey question that asks respondents to provide their average monthly costs for each fuel. When multiple utilities are included on one bill, respondents who rely on payment records instead of detailed bills cannot provide accurate estimates of the monthly cost of each fuel. These respondents often indicate that energy costs are included in rent when they use payment records to estimate energy costs.
} 


\subsubsection{Affected number of total households and refrigerators, and their energy consumption}

Besides the lack of variability in users' demand for refrigerator services, refrigerators are an unusual appliance in another way. Refrigerators are the only major appliance (apart from room air conditioners) for which many households have more than one unit. According to RECS there are approximately 18.1 million households with two or more refrigerators. Of these, only 400,000 are found in MFRs. To incorporate the secondary refrigerators into the stock of refrigerators affected by the PA problem, we simply allocated the secondary refrigerators by housing type into rental units using the ratio of rental units within the stock of each housing type. We assume that in no case in an occupant-owned unit is the secondary refrigerator not chosen by the occupant. ${ }^{7}$ We also assume that no secondary refrigerators fall into Case U. In other words, in rental units with landlord-paid utilities, landlords will not substantially add to their electric bills by leaving a second refrigerator in the unit. Allocating a proportional share of secondary refrigerators to rental units results in another 2.9 million refrigerators, nearly 2.6 million in SFRs. The total stock of affected refrigerators is 33.6 million or about $27 \%$ of the stock of refrigerators reported in RECS.

In order to calculate the energy consumed by the affected refrigerators the stock was subtotaled by units in SFRs and MFRs since the average household energy consumption differs substantially between the housing types. RECS disaggregates households by four types (SFRs, MFRs with 2 to 4 units, MFRs with 5 or more units, and mobile homes), but mobile home were aggregated with SFRs and all MFRs were lumped together and weighted average per household energy consumption figures were used in order to simplify the analysis. This split yields 15.1 million refrigerators in MFRs and 18.5 million in SFRs. Multiplying each of these figures by the respective average refrigerator consumption per household produces 39.3 billion $\mathrm{kWh}$ or 134 trillion site Btu associated with the affected refrigerators. This amounts to $25 \%$ of energy consumed for refrigeration and $1.4 \%$ of total 2001 residential site energy consumption. To convert this to primary energy we used data on total inputs to electricity generation (assuming $33 \%$ conversion efficiency for nuclear) and total consumption of electricity from the EIA's Electric Power Annual 2003 (U.S. EIA, 2004b). From this we derived a primary energy coefficient for electricity consumed of 2.94, which incorporates transmission and distribution losses. This yields 394 trillion Btu of PA associated primary energy or 2.2\% of total 2001 residential primary energy.

\footnotetext{
${ }^{7}$ While it is possible that the buyer of a previously owned unit may move into a house where the previous tenants left their refrigerator behind, we assume that this occurs in a small minority of cases. We could find no data on this phenomenon. In any event, occupants of such households always have the option of not using the "abandoned" refrigerator so in a sense they always choose the refrigerator.
} 


\subsubsection{Energy Savings}

In addition to calculating total energy associated with PA problems, we also estimated the possible savings from one year of refrigerator sales if all refrigerators sold that year were not affected by these split incentives. Ideally, we would have wanted data on the differences between the efficiencies of similarly sized refrigerators purchased by buyers who will pay the energy costs versus refrigerators bought by others on behalf of the utility payers. Unfortunately, RECS 2001 does not provide data on households where energy costs are included in rent or other fees. Thus, we had to make some assumptions to perform this estimate.

In order to estimate the savings that might arise from eliminating the PA barrier, we assume that removal of the PA barriers leads affected households to purchase Energy Star refrigerators at the same rate as households not affected by PA barriers. ${ }^{8}$ Due to the differences both in energy consumption and penetration of Energy Star models for refrigerators in SFRs compared to MFRs, we performed the calculations separately by housing unit type. About 38\% of refrigerators purchased for non-PA affected SFR households and about $20 \%$ of refrigerators purchased for non-PA affected MFR households in 2003 were Energy Star refrigerators. If the same rate applied to refrigerators purchased for PA-affected households, we estimate the resulting annual saving from 2003 sales would amount to 47.7 million $\mathrm{kWh}$ or 0.48 primary trillion Btus/year.

\subsection{Description of Principal-Agent Calculations for Water Heaters}

Data for the water heaters calculations were also taken from AHS 2003 and RECS 2001. The conceptual framework for determining the extent of the PA problem is the same as that shown in Table 1. Since end users do have some control over usage of hot water, the exception to the PA problem exhibited by refrigerators in Case U does not apply. In other words, landlords may choose an efficient water heater when they are paying the utility bill, but the occupants may take longer showers and use more hot water for laundry than they would otherwise.

Figure 2 demonstrates how the framework is applied in the case of residential water heating. For water heaters the classification is somewhat simpler than for refrigerators because renters and new home buyers rarely select their own water heaters. We found no data on the incidence of water heater choice in new homes. Thus, for purposes of allocating households into the various cases, we assumed that new home buyers never select their own water heaters. As discussed in the Introduction, occupant-owners who replace their own water heaters often do so

\footnotetext{
${ }^{8}$ The calculation of the savings potential is shown in greater detail in the Appendix.
} 
on an emergency basis. Data from a KEMA study show that water heaters were replaced due to sudden failure $41 \%$ of the time (KEMA Inc., 2005). This leaves an estimated 59\% of older occupant-owned units where owners actively choose their own replacement water heaters as the only category of end users not affected by a PA problem. The exceptions are older condo units whose buildings use central boilers to supply hot water (Case U) and older condo units with individual water heaters whose water heating fuel is included in condo fees (Case B). Table 3 aggregates the households in Figure 2 by case.

\subsubsection{Case $N$}

The average lifespan of a water heater is approximately thirteen years. In order to calculate the number of units with no PA problem (Case N), the occupant-owned SFRs (including mobile homes) where the water heater has been replaced at least once were estimated by subtracting the number of occupant-owned SFR units constructed between 1990 and 2003 (estimated from AHS data - 95\% of all occupant-owned units constructed in that period) from the total number of occupant-owned SFRs. Then, 59\% of this difference results in 31.8 million SFR and mobile home households in Case $\mathrm{N}$ with no PA problem. In order to determine which occupant-owned MFR units have no PA problem, older condos with central boilers or with the water heating fuel included in fees are subtracted from the set of older condos. Data limitations in the AHS tables did not allow a cross-tabulation of condominiums by water heater fuel and fuel types included in fees. However, 0.9 million occupant-owned MFR units are listed as having a steam or hot water heating system (U.S. Census Bureau, 2005a). Adjusting for the number of those that are greater than thirteen years old leaves 0.7 million units. Subtracting this number from all older occupant-owned MFRs and multiplying by 59\% places another 1.1 million households in Case $\mathrm{N}$ for a total of 33.0 million households. ${ }^{9}$

\footnotetext{
${ }^{9}$ The total is slightly higher due to rounding.
} 
Figure 2. Water Heater Decision Tree for Allocating Households to Four Principal-Agent Cases, Million Housing Units

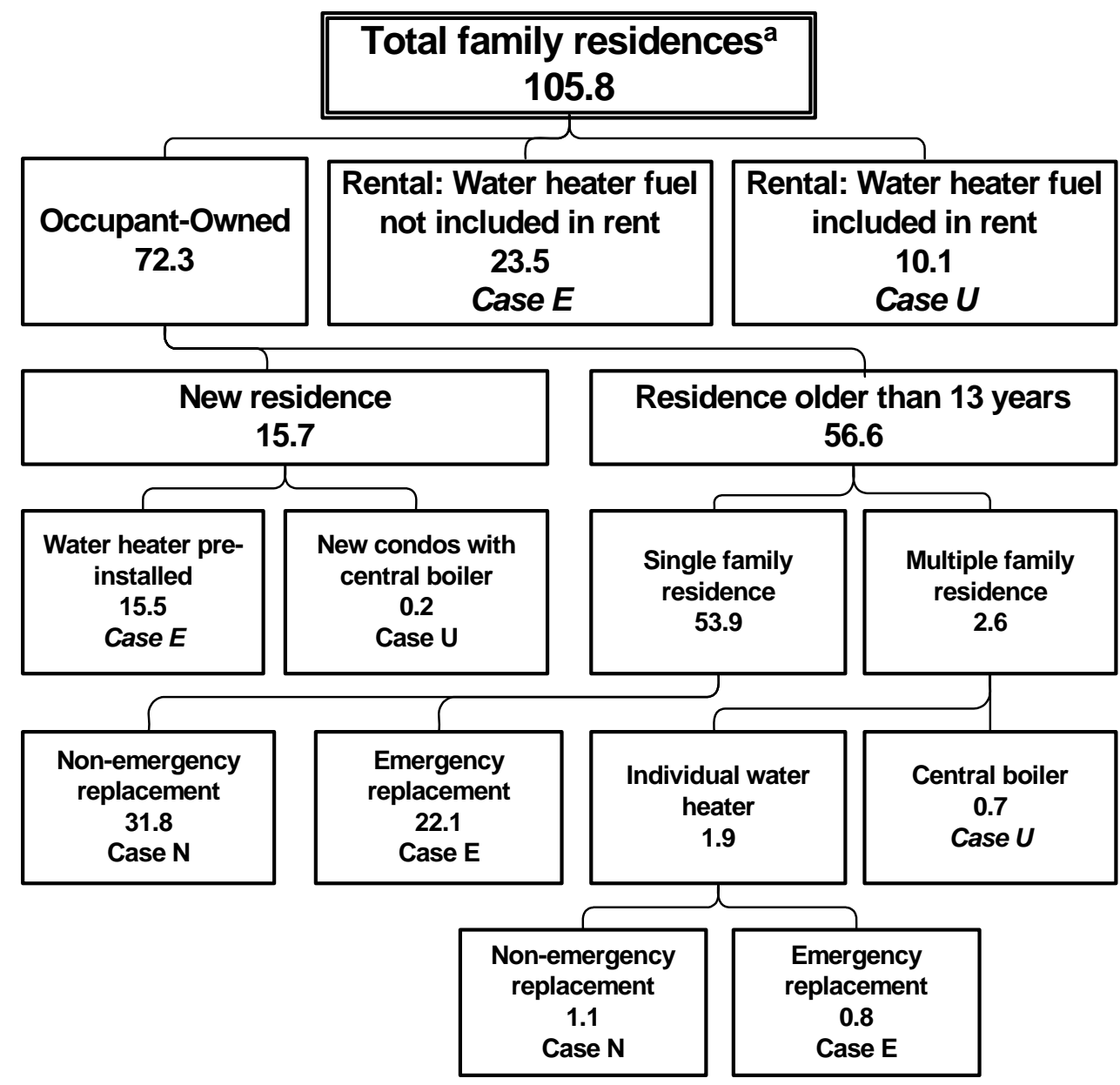

${ }^{a}$ Numbers in parent categories will not always equal the sum of subordinate categories due to rounding.

\subsubsection{Cases $E, B$, and $U$}

Case $\mathrm{E}$ consists of most rental units, all newer occupant-owned residences, and $41 \%$ of older occupant-owned residences. We assume that new home or condo buyers rarely specify the model of water heater to be installed. The AHS data indicate 15.7 million occupant-owned residences were completed in the past thirteen years. From these we subtracted the 0.19 million newer condos that have central steam heating systems, which we assume also provides hot water. These were moved from Case $\mathrm{E}$ to Case $\mathrm{U}$ since units with centrally heated water will not be billed individually for the water heating fuel. The 0.68 million older condos with central steam or hot water systems also fall into Case U.

For older occupant-owned residences where the water heater has been replaced at least once, but the occupant did not choose the water heater because of a catastrophic failure of the 
water heater, $41 \%$ of the older SFR and mobile home stock yields 22.1 million households in Case E. To calculate the condo units that fall into Case E, the number of older units was adjusted by the estimated units with central water heating. Of those 1.9 million households, 0.8 million are assigned to Case E.

In addition to a large portion of occupant-owned units we include all rental units in Case E, except those where the water heating fuel is included in rent, which fall in to Case U. Since the AHS data only indicate the number of housing units for which a given fuel's cost is included in rent or other fees, some assumptions were necessary in order to estimate the number of households whose water heating fuel is included in rent or fees. Using AHS data, we allocated the rental units with electricity included in rent to households assumed to use electricity as water heating fuel using the ratio of electric water heating units in the entire rental stock. For the number of rental units listed as having natural gas or fuel oil included in rent or fees, we assumed that all of these units have water heating by those fuels since these fuels are generally used for both space and water heating when available. Of the 33.6 million rental units, we estimate 11.0 million fall into Case U, and the remaining 23.5 fall into Case E. Due to data constraints we did not calculate households belonging to Case $\mathrm{B}$, but the number of instances would be negligible.

Table 4. Water Heaters by Number and Share of Households and Site Energy

\begin{tabular}{|c|c|c|}
\hline & Can Choose Device & Cannot Choose Device \\
\hline $\begin{array}{l}\text { Direct Energy } \\
\text { Payment }\end{array}$ & $\begin{array}{l}\text { Case N: } 33.0 \text { million [31\%] } \\
\quad 569 \text { TBtu [34\%], } 552 \text { PJ } \\
59 \% \text { of occupant-owned SFRs older than } \\
13 \text { years } \\
59 \% \text { of occupant-owned MFRs, older } \\
\text { than } 13 \text { years, w/ individual water } \\
\text { heaters, util not included }\end{array}$ & $\begin{array}{l}\text { Case E: } 61.9 \text { million [59\%] } \\
\quad 954 \text { TBtu [57\%], } 925 \text { PJ } \\
\text { Most rental units } \\
\text { Newer occupant-owned units } \\
60 \% \text { of occupant-owned units, older } \\
\text { than } 13 \text { years, w/ individual water } \\
\text { heaters }\end{array}$ \\
\hline $\begin{array}{l}\text { Indirect Energy } \\
\text { Payment }\end{array}$ & $\begin{array}{l}\text { Case B: Negligible } \\
\text { Possibly a small number of condos older } \\
\text { than } 13 \text { years w/ individual water heaters }\end{array}$ & $\begin{array}{l}\text { Case U: } 11.0 \text { million [10\%] } \\
\quad 157 \text { TBtu [9\%], } 152 \text { PJ } \\
\text { Significant number of rental units } \\
\text { Condos with central boilers } \\
\text { Newer condos with utilities included }\end{array}$ \\
\hline
\end{tabular}

${ }^{\mathrm{a}}$ Assumes original water heater has been replaced by owner.

\subsubsection{Affected number of total households, and their energy consumption}

In order to calculate the energy consumed for water heating by the 72.9 million households that are affected by the PA problem, the total number of affected units was disaggregated by household type using the AHS data. This was necessary because average energy consumption for water heating varies by unit type. According to RECS, the energy used for water heating varies from 10 million Btu in households in MFR buildings with 5 or more units to 17.9 million Btu in SFRs (U.S. EIA, 2004a). Averages for smaller MFR buildings and mobile homes 
were in between. Multiplying the number of households by the RECS average water heating energy consumption for each household unit type yields an estimate of 1,111 trillion Btu of site energy associated with the PA problem.

Estimating total primary energy associated with the PA problem required additional steps in order to produce a separate estimate of the share of electricity in the total energy associated with PA problems. RECS figures on total consumption by household by fuel and household type were apportioned to units on the basis of the shares of each type of housing unit affected by the PA problem. For example, 44.8 million of 74.0 million (non-mobile) SFR households were determined to be affected by the PA problem for water heaters. Total natural gas consumed for water heating in SFRs was 930 trillion Btu so roughly 61\% (54.2 million divided by 74.0 million) of the natural gas consumed for water heating is estimated to occur in PA affected SFRs. Continuing this calculation for the other fuels and household types results in 863 trillion Btu of direct fossil fuel combustion and 234 trillion Btu (69.2 billion $\mathrm{kWh}$ ) of electricity. This is roughly $66 \%$ of the 1,680 trillion Btu RECS shows for total water heater site energy and $11 \%$ of total residential site energy consumption. Multiplying the total for electricity by the primary energy factor described above yields 813 trillion Btu of primary energy for electricity for a total of 1561 trillion Btu of primary energy or $8.4 \%$ of total residential primary energy.

\subsubsection{Energy Savings}

Using an approach similar to that used to estimate potential refrigerator savings, we estimated annual savings from one year's worth of water heater sales. Data from the Gas Appliance Manufacturers' Association show that 9.55 million water heaters were shipped in the U.S. in 2003 (GAMA, 2005). A small number of LPG and fuel oil water heaters are sold, but GAMA does not supply data on them. Among gas and electric water heaters, 54\% were gas.

The Census data on housing completions allowed us to determine how many water heaters were needed for new SFRs (1.3 million), MFRs (0.3 million), and mobile homes (0.07 million) (U.S. Census Bureau, 2005b; U.S. Census Bureau, 2005c). This leaves 7.9 million water heaters purchased as replacements. Of these, we assume that $41 \%$ were purchased as emergency replacements. Since we did not have data on main water heating fuel by year of completion, the 2003 total shares of gas and electric water heaters were applied to each category of housing type. These were allocated to rental units by unit type on the basis of the share of each rental housing unit type in the total stock. For example, since rental MFRs constitute 20\% of the total housing stock, $20 \%$ of the replacement water heaters purchased were assumed to be for rental MFRs. Altogether, an estimated 3.4 million gas water heaters and 3.0 million electric water heaters shipped in 2003 (67\% of all water heaters shipped that year) were subject to PA problems. 
With RECS data on average water heating consumption by housing unit type and fuel and an adjustment to assign minimum efficiency to the PA-affected water heaters, we find that 66 trillion Btu of natural gas and 25 trillion Btu of electricity (141 trillion Btu of total primary energy) will be consumed by these water heaters each year. Using data from the Technical Support Document for the water heater standards enacted in 2001 on the shipments of water heaters by efficiency level for each fuel, we estimated the average efficiencies of water heaters shipped to PA and non-PA affected households (U.S. DOE, 2000). ${ }^{10}$ Applying the average efficiency of non-PA affected water heaters to the $67 \%$ of affected water heaters yields an estimated annual savings from 2003 sales of water heaters of 4.6 trillion Btu of site energy and 5.9 trillion Btu of primary energy. As an additional estimate of potential savings, we estimated that annual savings from individual billing of the entire stock of units included in Case U could be as high as 15 to 30 trillion Btu of site energy, assuming a $10 \%$ to $20 \%$ reduction in usage due to billing. This range was selected on the basis of a study on the impact of submetering on water use in MFRs that found an average 15\% reduction compared to master-metered apartments (Mayer et al., 2004).

\subsection{Description of Principal-Agent Calculations for Space Heating}

The factors determining the presence of PA problems for space heating are nearly identical to water heating, which allowed us to expand the coverage of this study to include space heating. ${ }^{11}$ As with water heating, there are two types of PA problems: disincentives to efficiency in equipment purchases and disincentives to thrifty consumption. The former occurs when users are not able to choose their own equipment affecting the use of space heating and the latter when users do not incur a cost proportional the amount of energy consumed.

As with water heating, the most important characteristics for allocating housing units have to do with their tenancy status, age, and inclusion of energy costs into flat or common fees. Figure 2, the decision tree used to disaggregate the housing units by the PA typology for water heating, applies to space heating as well, although the number of units in each case differs as described below. ${ }^{12}$ In rental households, tenants will almost never have any influence on the choice of furnaces and other major structural items (such as windows and ceiling or wall insulation) that affect space heating. Virtually all rental households are affected by PA problems.

\footnotetext{
${ }^{10}$ The method is described more fully in the Appendix.

${ }^{11}$ However, calculations of savings potential for space heating are complex and did not fall under the scope of the present study.

12 For space heating, we do not make an estimate for emergency replacements. All replacements by occupant-owners who directly pay for their heating energy are classified as Case N.
} 
When tenants pay a proportional energy cost they fall into Case E. When energy costs are included in fees or are billed in common, units fall into Case U.

Residents in occupant-owned units theoretically do have control over equipment choices, but as with water heaters, we assume that home new home buyers rarely specify the equipment installed. Occupants do have the opportunity to make these purchase decisions when furnaces or other equipment have reached the end of their useful lives and need to be replaced. The exception occurs for condo owners with centrally supplied steam heat since they can rarely choose their heating equipment.

Although several factors affect space heating demand - furnace efficiency, R-rating of insulation, U-value of windows - we have chosen to focus on furnace replacement to define which owner-occupied residences count as "old" for purposes of determining in which households the occupants have chosen their space heating equipment. Furnace lifetimes are generally estimated at 20 years, so this vintage is used to split the housing stock into older and newer units. This means that more occupant-owned units are affected by PA problems for space heating than for water heating since water heaters are replaced more often.

\subsubsection{Case $N$}

Similar to water heating, Case $\mathrm{N}$ households are composed essentially of older occupantowned units, in which occupants have had to replace original equipment and therefore had the opportunity to choose it. In order to determine the number of households in Case N, the number of older units must be disaggregated by unit type. This is particularly important for space heating since the average energy consumption per household for heat differs widely among SFRs, MFRs, and mobile homes. AHS only provides data on year of construction by tenancy status (owned vs. rented) but not by unit type. Like previous calculations, the newer occupant-owned units (those built since 1985) were separated from the whole stock. It was assumed that the proportion of condos and mobile homes among all occupant-owned units has not changed significantly over time, so these older units were allocated to unit types based on the proportions in the total stock. A correction in the number of condos was made to account for those units served by central steam boilers. The number of condos with central steam heating was divided into newer and older units in proportion to the newer and older shares in the total stock of condos. These calculations resulted in 44.9 million SFRs; 1.8 million MFRs, and 3.9 million mobile homes falling in Case N. Together, these households consume approximately 2,450 TBtu of site energy per year for space heating, or about $53 \%$ of site energy for heating. 


\subsubsection{Case E}

Case E households consist of most rental units and those occupant-owned units built within the last 20 years. Rental units with fuel costs included in the rent and newer condos with central steam heating systems are the exceptions. The number of boiler-heated condos was determined for Case $\mathrm{N}$, so these were subtracted from the stock of new condos.

In order to determine the number of units where the space heating fuel cost is included in rent, some reasonable assumptions had to be made because the AHS data do not cross-tabulate the main space heating fuel by whether that fuel is included in rent. We assumed that for apartments where electricity is included in rent electricity is not the main space heating fuel, reasoning that landlords would shield themselves from the large expenditures that electric heating can entail. In contrast, we assumed that where natural gas or fuel oil is included in rent or other fees, they are the main space heating fuel. We assumed that fuel oil and gas are rarely used by the same household, although it is possible that some apartments with fuel oil fired central steam or hot water heating could also have natural gas for water heating and cooking. We suspect this number is small. Our calculations result in 29.1 million SFRs, 14.5 million MFRs, and 2.5 million mobile homes in Case E. These homes consume roughly 1,860 TBtu of site energy for space heating, about $40 \%$ of the total.

\subsubsection{Case B}

These units would consist of condos with individual electric or natural gas heaters where that fuel is included in condo fees. However, we assume this number to be negligible.

\subsubsection{Case $U$}

Case $U$ units consist of the rental units with space heating fuel costs included and condos with central steam systems. This amounts to 8.7 million MFRs and 0.5 million mobile homes.

These units consume 350 TBtu of site energy for heating, which accounts for $8 \%$ of the total heating energy. Table 5 summarizes the distribution of households and energy consumption by PA category. 
Table 5. Space Heating by Number and Share of Households and Site Energy

\begin{tabular}{|l|l|l|}
\hline $\begin{array}{l}\text { Direct Energy } \\
\text { Payment }\end{array}$ & $\begin{array}{l}\text { Can Choose Device } \\
\text { Case N: 50.6 million [48\%] } \\
\text { 2,447 TBtu [53\%], 2,370 PJ } \\
\begin{array}{l}\text { Occupant-owned SFRs older than 20 } \\
\text { years } \\
\text { Occupant-owned older MFRs, older than } \\
\text { 20 years, individual space heaters, util } \\
\text { not included }\end{array}\end{array}$ & $\begin{array}{l}\text { Case E: 46.1 million [44\%] } \\
1,860 \text { TBtu [40\%], 1,802 PJ } \\
\text { Most rental units, excl where util } \\
\text { included } \\
\text { Newer occupant-owned units, excl } \\
\text { condos w/ central steam heating }\end{array}$ \\
\hline $\begin{array}{l}\text { Indirect Energy } \\
\text { Payment }\end{array}$ & $\begin{array}{l}\text { Possibly a small number of condos older } \\
\text { than 20 years w/ individual water heaters } \\
\text { and space heating fuel incl in rent }\end{array}$ & $\begin{array}{l}\text { Case U: 9.1 million [9\%] } \\
\text { 350 TBtu [8\%], 341 PJ } \\
\text { Rental MFRs and mobile homes } \\
\text { with space heating fuel incl in rent } \\
\text { Condos with central boilers } \\
\text { Newer condos with utilities included }\end{array}$ \\
\hline
\end{tabular}

${ }^{\mathrm{a}}$ Assumes original space heater has been replaced by owner.

\subsection{Description of Principal-Agent Calculations for Residential Lighting}

Data on electricity used for lighting are taken from an EIA website (U.S. EIA, 2005) that provides more detailed information on electricity consumption than can be found in the main published RECS tables. Additional data on square footage are from the U.S. EIA (2004c) and number of households and inclusion of electricity in rent data are from AHS 2003. The decision tree for classifying residential lighting is the most simple of the four end-uses examined. The fact that light bulbs, whether incandescent or fluorescent, are such a small and inexpensive device means that end users almost always control the device selection. The exception occurs for fixtures that are hard-wired for only one type of bulb, such as fluorescent tube lighting or downlighting that is only compatible for one type of bulb. In recent years, downlighting for common areas has become more common in new homes. Since we did not find data on the current saturation of nonCFL downlights or fluorescent tubes by housing unit type, we did not incorporate the energy associated with these fixtures into our analysis. ${ }^{13}$ However, assumptions regarding the stock of residential fixtures that are CFL-incompatible downlights have an enormous effect on the calculation of associated energy (see Table 7). For most standard screw-in fixtures and lamps, the only case in which a PA problem arises, is that in which end users do not pay the cost of electricity. The allocation of households to the various cases is discussed below and summarized in Table 6.

\footnotetext{
${ }^{13}$ In response to this trend, the recent revision to California's Title 24 building codes requires new housing to use downlighting fixtures that are hard-wired for CFLs.
} 


\subsubsection{Case $N$}

Over 95\% of all households fall into Case N. This includes all 74 million SFRs although some SFRs do report having electricity included in rent or other fees (see footnote 6). Case $\mathrm{N}$ also includes the 8.4 million occupant-owned mobile homes and MFRs and 18.5 million rented mobile homes and MFRs where tenants pay their own electricity bills.

\subsubsection{Cases $E$ and $U$}

The number of households where occupants are not able to choose their lighting technologies was deemed to be negligible.

\subsubsection{Case $B$}

Households in Case B consist of the 0.1 million rented mobile homes, 4.3 million rented MFRs, 0.2 million occupant-owned mobile homes, and 0.3 million occupant-owned MFRs where electricity is included in rent or other fees. The total, 4.9 million, is less than $5 \%$ of U.S. households.

Table 6. Residential Lighting by Number and Share of Households and Site Energy

\begin{tabular}{|l|l|l|}
\hline & Can Choose Device & Cannot Choose Device \\
\hline $\begin{array}{l}\text { Direct Energy } \\
\text { Payment }\end{array}$ & $\begin{array}{l}\text { Case N: 101.0 million [95\%] } \\
\text { 335 TBtu [98\%], 353 PJ }\end{array}$ & Case E: negligible \\
& $\begin{array}{l}\text { Occupant-owned and rented SFRs } \\
\text { Most occupant-owned MFRs and mobile } \\
\text { homes } \\
\text { Most rental MFRs and mobile homes }\end{array}$ & \\
\hline $\begin{array}{l}\text { Indirect Energy } \\
\text { Payment }\end{array}$ & $\begin{array}{l}\text { Case B: 4.9 million [5\%] } \\
7.8 \text { TBtu [2\%], 8.2 PJ }\end{array}$ & Case U: negligible \\
& $\begin{array}{l}\text { Some rented MFRs and mobile homes } \\
\text { Small number of occupant-owned MFRs }\end{array}$ & \\
\hline
\end{tabular}

\subsubsection{Affected number of total households and their energy consumption:}

In order to estimate the amount of lighting electricity consumption associated with the PA problem, we assumed that to first order, demand for lighting scales proportionally to the square footage of households. Using data from the U.S. EIA (2004c), and number of households by housing unit type from AHS 2003, we estimated the total square footage of the affected MFRs and mobile homes. This worked out to be a little over 5 billion square feet (470 million square meters). Total square footage for all households was estimated to be approximately 221 billion square feet (20.5 billion square meters). The share of affected square footage is therefore estimated to be approximately $2.3 \%$. The share of square footage is lower than the share of households because MFRs and mobile homes are significantly smaller on average than SFRs. The 
share of affected square footage was applied to the 100.5 terawatt-hours (TWh) of electricity used for residential lighting (US EIA, 2005). The result, 2.3 TWh (7.9 trillion Btu), is less than $0.1 \%$ of total residential site energy. Converted to primary energy (23 trillion Btu) the share climbs to a little over $0.1 \%$.

\subsubsection{Energy Savings}

Energy savings by overcoming the PA problem for residential lighting would be negligible for two reasons. First, the total amount of PA associated energy is quite small. Second, informational and other barriers appear to be primarily responsible for the low market share of efficient lamps, since the proportion of fluorescent lamps constitutes only $6 \%$ of all residential lamps sold in the U.S. (including tubular lamps) (Itron, 2004). Even in households with no PA problem, incandescent and halogen bulbs account for a wide majority of lamps sold.

\subsection{Sensitivity Analysis of Key Assumptions}

Many assumptions had to be made in order to derive the estimates of associated energy and energy saving potential for the end uses described above. Most of these assumptions concerned the allocation of the housing stock into various levels of housing unit type, tenancy status, inclusion of fuel costs in rent or other fees, and main fuel type for space heating and water heating. Assumptions were necessary due to a lack of data for various combinations of these criteria. In other cases, a data point existed for one year and had to be applied to other years for which data were missing. Rough estimates were also made of the energy usage for some end uses and the effect on consumer choices from removing PA barriers.

We conducted a sensitivity analysis to investigate the effect of changing the values for the key assumptions. Values were increased or decreased based on reasonable counterassumptions, and the corresponding changes in energy consumption or savings were noted. The results, organized by end use, are shown in Table 7.

The assumption with the largest impact on the energy used by refrigerators affected by the PA problem is that purchasers of SFRs with the pre-installed refrigerators cannot choose Energy Star models. Changing the assumption such that half the buyers are offered an Energy Star option lowers the PA associated energy by over $11 \%$. The second most important assumption for refrigerators concerns the retroactive application of the share of SFRs built in 2003 that had refrigerators pre-installed (45\%). Because we did not have data to indicate whether this figure has remained relatively steady since 1990 , we changed the assumed average share by $\pm 15 \%$ to account for the possibility that the share of pre-installs was significantly higher or lower in previous years. To calculate refrigerator savings, we assumed that all Energy Star refrigerators 
are shipped to households not affected by PA barriers. A large impact was observed on estimated savings based on changing this assumption. If PA affected households receive Energy Star refrigerators at half the rate of the total average (which would be 15\% of PA affected SFRs and 3\% of PA affected MFRs) the estimated savings also falls by half.

For water heating, one important assumption influencing the estimate of associated energy is that new home buyers never choose their own water heater. Changing that assumption to allow $20 \%$ of new home buyers to select their own water heaters decreases the associated energy by $7.5 \%$. The assumption with the largest effect on associated energy is that the number of rental MFR households reporting natural gas included in rent is correct. If half of those are misreported, the total associated site energy falls by a third. As with refrigerators, the main assumption on the estimate of annual savings from eliminating the PA problem for year 2003 sales is all efficient models are shipped to non-PA affected households. Allowing for PA households to received efficient models at half the total average rate also lowers the estimated savings for water heaters by half. The largest impact on savings that would result from individually billing the stock of rental units where fuel costs are included in rent or fees is the assumption that units reporting natural gas included in rent are reporting accurately, and that these units use natural gas as their heating fuel. Assuming that half of these units are misreports lowers the savings estimate by a third. 
Table 7. Sensitivity Analysis of Key Assumptions on Estimates of Associated Energy and Energy Saving Potential from Removing Principal-Agent Barriers ${ }^{\text {a }}$

\begin{tabular}{|c|c|c|c|}
\hline Description of Assumptions Used & Counter-Assumptions & $\begin{array}{l}\text { \% Change in } \\
\text { Associated } \\
\text { Energy }\end{array}$ & $\begin{array}{l}\text { \% Change in } \\
\text { Savings from One } \\
\text { Year's Sales }\end{array}$ \\
\hline \multicolumn{4}{|l|}{ Refrigerators } \\
\hline $\begin{array}{l}\text { Since only one year's data (2003) were available from NAHB on } \\
\text { the rate of pre-installed refrigerators, the same rate was assumed to } \\
\text { apply for all "new" stock of SFRs. }\end{array}$ & $\begin{array}{l}\text { Assume that the rate has changed markedly over } \\
\text { time, and that previous years had either a much } \\
\text { higher or lower rate of pre-installs than } 2003 \\
\text { resulting in average rate for all } 15 \text { years changing by } \\
\pm 15 \% \text {. }\end{array}$ & $\pm 7.5 \%$ & \\
\hline $\begin{array}{l}\text { Since we could find no data on the percentage of buyers of } \\
\text { developer-built homes who are able to select Energy Star } \\
\text { refrigerators as a pre-installed option, we assumed that all } 45 \% \text { of } \\
\text { newer homes with pre-installed refrigerators are subject to the PA } \\
\text { barrier. }\end{array}$ & $\begin{array}{l}\text { Assume that builders offered an Energy Star option } \\
\text { in half of the homes with pre-installed refrigerators. }\end{array}$ & $-11.3 \%$ & \\
\hline $\begin{array}{l}\text { Data provided by NAHB did not differentiate between condo and } \\
\text { rental MFRs. We assumed the same rate applied to both. }\end{array}$ & $\begin{array}{l}\text { Assume condo buyers chose refrigerator } 45 \% \text { of the } \\
\text { time, the same rate that applies to new SFRs. }\end{array}$ & $-0.8 \%$ & \\
\hline $\begin{array}{l}\text { Rate of pre-installed refrigerators for } 2003 \text { MFRs applies to entire } \\
\text { rental MFR stock. }\end{array}$ & $\begin{array}{l}\text { Assume that on average 95\% of MFR renters do not } \\
\text { choose refrigerator because NAHB data do not } \\
\text { capture instances where landlords have refrigerators } \\
\text { installed after construction is completed. } \\
\end{array}$ & $+5.4 \%$ & \\
\hline $\begin{array}{l}\text { Because communication with Census Bureau staff led us to believe } \\
\text { that many HH reporting gas and electricity included in rent are } \\
\text { misreports, particularly SFRs, we have assumed that all rental SFR } \\
\text { units with electricity included in rent are misreports. }\end{array}$ & $\begin{array}{l}\text { Only half of rental SFRs with electricity included are } \\
\text { misreports. }\end{array}$ & $+2.0 \%$ & \\
\hline $\begin{array}{l}\text { Since we know that some rental SFRs do have electricity or gas } \\
\text { included in rent, we compensated by assuming that all MFRs } \\
\text { reporting electricity included in rent are accurate. }\end{array}$ & $\begin{array}{l}\text { Half of reported electricity included units are } \\
\text { misreports. }\end{array}$ & $-5.4 \%$ & \\
\hline $\begin{array}{l}\text { Most HH reporting a secondary refrigerator are SFRs. These } \\
\text { refrigerators were divided proportionally among rental \& occupant- } \\
\text { owned SFRs based on their shares of the SFR stock. }\end{array}$ & $\begin{array}{l}\text { Assume rentals greater or lesser than proportional } \\
\text { share by } \pm 5 \% \text {. }\end{array}$ & $\pm 4.2 \%$ & \\
\hline $\begin{array}{l}\text { Assumed that } 25 \% \text { of SFR renters use own refrigerator, somewhat } \\
\text { more than the estimate for MFR renters. }\end{array}$ & $\begin{array}{l}15 \% \text { of SFR renters use own refrigerator, same as the } \\
\text { estimated MFR share. }\end{array}$ & $+4.1 \%$ & \\
\hline $\begin{array}{l}\text { Assumed that no refrigerators shipped for PA affected households } \\
\text { are Energy Star models. }\end{array}$ & $\begin{array}{l}\text { Assume that } 15 \% \text { of PA affected SFRs and 3\% of PA } \\
\text { affected MFRs (half of the total rate for each housing } \\
\text { unit type) received Energy Star models. }\end{array}$ & & $-50 \%$ \\
\hline
\end{tabular}




\begin{tabular}{|c|c|c|c|}
\hline Description of Assumptions Used & Counter-Assumptions & $\begin{array}{l}\text { \% Change in } \\
\text { Associated } \\
\text { Energy }\end{array}$ & $\begin{array}{l}\text { \% Change in } \\
\text { Savings from One } \\
\text { Year's Sales } \\
\end{array}$ \\
\hline \multicolumn{4}{|l|}{ Water Heating } \\
\hline $\begin{array}{l}\text { New SFR and condo buyers never specify the type of water heater } \\
\text { installed. }\end{array}$ & $\begin{array}{l}\text { Assume } 20 \% \text { of new SFR and condo buyers choose } \\
\text { water heater. }\end{array}$ & $-7.5 \%$ & \\
\hline $\begin{array}{l}\text { Replacements of water heaters by occupant-owners are done on an } \\
\text { emergency basis } 41 \% \text { of the time. }\end{array}$ & Change the rate of emergency replacement by $\pm 20 \%$ & $\pm 17 \%$ & \\
\hline $\begin{array}{l}\text { Assume that no efficient water heaters are shipped to PA affected } \\
\text { households. }\end{array}$ & $\begin{array}{l}\text { Assume that } 15 \% \text { of gas water heaters and } 10 \% \text { of } \\
\text { electric water heaters shipped to PA affected } \\
\text { households (half the average percentage) are } \\
\text { efficient. }\end{array}$ & & $-50 \%$ \\
\hline All MFR reports of electricity included are accurate. & Half of MFR electricity included are misreports. $^{b}$ & $\begin{array}{l}-3.7 \% \text { site } \\
-9.6 \% \text { primary }\end{array}$ & \\
\hline $\begin{array}{l}\text { For rental MFRs with electricity included in rent, the share of } \\
\text { electricity as WH fuel is the same as entire rental MFR stock } \\
(43 \%) \text {. }\end{array}$ & $\begin{array}{l}\text { Assume only } 30 \% \text { of rental MFR units with elec } \\
\text { included use elec as WH fuel because landlords less } \\
\text { likely to include elec in rent where elec used for large } \\
\text { end uses such as water or space heating. }\end{array}$ & $\begin{array}{l}-2.2 \% \text { site } \\
-5.7 \% \text { primary }\end{array}$ & \\
\hline $\begin{array}{l}\text { All rental MFR units reporting natural gas included in rent are } \\
\text { accurate. }\end{array}$ & $\begin{array}{l}\text { Only half of rental MFR units reporting natural gas } \\
\text { included in rent are accurate. }\end{array}$ & $\begin{array}{l}\text { - 33.3\% site } \\
-29.1 \% \text { primary } \\
\end{array}$ & \\
\hline \multicolumn{4}{|l|}{ Space Heating } \\
\hline $\begin{array}{l}\text { Units defined as "new” based on } 20 \text {-yr furnace lifetime, resulting } \\
\text { in } 29 \% \text { of units classified as new. }\end{array}$ & Adjust “new” units by $\pm 7 \%$ & $\pm 11.1 \%$ & \\
\hline New home buyers never choose furnace, insulation, windows, etc. & $\begin{array}{l}20 \% \text { of new home buyers choose space heating- } \\
\text { related features. }\end{array}$ & $-13.5 \%$ & \\
\hline $\begin{array}{l}\text { Data on composition of housing by year of construction were not } \\
\text { available, assumed that "New" occupant-owned units composed of } \\
\text { SFR/MFR/mobile at same proportion as total stock. }\end{array}$ & $\begin{array}{l}\text { Assume the case that increases energy consumption } \\
\text { the most: all new occupant-owned units are SFRs. }\end{array}$ & $+2.5 \%$ & \\
\hline \multicolumn{4}{|l|}{ Lighting } \\
\hline All rental SFRs with electricity included are misreports. & $\begin{array}{l}\text { Only half of rental SFRs with electricity included are } \\
\text { misreports. }\end{array}$ & $+12.4 \%$ & \\
\hline $\begin{array}{l}\text { All rental MFRs and mobile homes w/ electricity included are } \\
\text { accurate. }\end{array}$ & $\begin{array}{l}\text { Half of rental MFRs and mobile homes w/ electricity } \\
\text { included are misreports. }\end{array}$ & $-45.0 \%$ & \\
\hline $\begin{array}{l}\text { All occupant-owned mobile and MFRs w/ electricity included are } \\
\text { accurate. }\end{array}$ & $\begin{array}{l}\text { Half of occupant-owned MFRs with electricity } \\
\text { included are misreports. }\end{array}$ & $-5.0 \%$ & \\
\hline No CFL incompatible downlight fixtures are accounted for. & $\begin{array}{l}\text { Assume } 10 \% \text { of SFR square footage is lit by CFL } \\
\text { incompatible downlight fixtures. }\end{array}$ & $+372 \%$ & \\
\hline
\end{tabular}

Effect on site energy unless otherwise noted.

b Assumptions and sensitivity results also apply to the stock-wide estimated savings from individual metering. 
The estimate of PA associated energy used for space heating is strongly influenced by two values. The first is the assumption that new home buyers never choose their own furnaces and other heating-related features. In many cases this may not be true. If the percentage of new home buyers selecting their own heating and insulating features were $20 \%$, associated energy use would fall by $13.5 \%$. For heating, it is difficult to define precisely what constitutes a "new" occupant-owned house, since multiple features affect demand for heating fuel. We chose 20 years based on a rough estimate of furnace lifetime, which results in $29 \%$ of occupant-owned units. Increasing or decreasing that share by $7 \%$ (about a fourth of the "new" population) yields a corresponding change in associated energy of $\pm 11 \%$.

With lighting the main assumption is that, due to lack of data, we did not account for CFL-incompatible downlighting. If only $10 \%$ of the stock of SFR lighting energy is used in such fixtures (assuming these fixtures were chosen by the builders or landlords) the associate energy increases by $372 \%$. Another important issue concerns the accuracy of the units reporting electricity as being included in rent or other fees in the AHS (U.S. Census Bureau, 2005a). Of particular importance is the assumption that the AHS figures are accurate for rental MFRs and mobile homes.

\section{$4 \quad$ Discussion}

One aspect of the PA problem that warrants further consideration is the role of information in relation to PA problems. Recall that PA problems arise when certain conditions are met: incentives are misaligned between a principal and his or her agent, the agent's actions incur some cost for the principal, information is asymmetric, and monitoring or constraining the agent's actions is impossible or too costly. In some cases, incentives are not fundamentally misaligned but are misaligned in practice due to information barriers. Bear in mind that in our results we have attempted to exclude energy consumption that is primarily associated with information problems.

In the Case E subset of our PA categorization, the problem is thought to occur because home builders and rental unit owners assume that occupants are unaware of or less sensitive to household operating costs than to the purchase or rental price. In order to recoup the cost of any energy efficient equipment that is more expensive than standard equipment, buyers or tenants will have to be convinced that higher housing costs will be recovered through energy savings. However, obtaining all of the information necessary and performing the financial calculations to verify the advantages of energy efficient equipment are daunting tasks. The better the information, the less a PA problem truly exists. For example, a landlord may wish to equip all the 
units in a building with energy efficient refrigerators, water heaters, washers, and other end uses, but if higher rents have to be charged to cover the additional expenses, it may be difficult to convince prospective renters that energy savings will offset the higher rent compared to other apartments of similar size and quality. Prospective tenants may need to see a detailed breakdown of the equipment costs and projected energy savings to accept higher rents. Many programs address information barriers for the end-uses covered in this study: appliance labeling, Energy Star, the Home Energy Rating System, and energy-efficient mortgages. Given the scope of this study, no attempt was made to estimate the extent to which these programs have mitigated the impact of the PA barriers examined here.

With the high prevalence of PA barriers, what policies should be enacted to mitigate them? In Table 8 we have attempted to match each cell of the PA matrix (Table 1) to the policies that are best suited to overcoming the PA circumstances characterized in that cell.

Table 8. Principal-Agent Matrix Matched to Appropriate Policies

\begin{tabular}{|l|l|l|}
\hline Direct Energy Payment & Can Choose Device & Cannot Choose Device \\
& $\begin{array}{l}\text { Case N: } \\
\text { end use performance standards } \\
\text { building codes } \\
\text { appliance labels } \\
\text { home energy rating and labeling } \\
\text { rebates directed toward end users }\end{array}$ & $\begin{array}{l}\text { Case E: } \\
\text { end use performance standards } \\
\text { building codes } \\
\text { home energy rating and labeling } \\
\text { rebates directed toward builders \& } \\
\text { landlords }\end{array}$ \\
\hline Indirect Energy Payment & $\begin{array}{l}\text { Case B: } \\
\text { end use performance standards } \\
\text { building codes } \\
\text { require landlords and condo } \\
\text { managers to provide prompt } \\
\text { information to tenants about } \\
\text { energy consumption and costs } \\
\text { individual metering requirements }\end{array}$ & $\begin{array}{l}\text { building codes } \\
\text { require landlords to provide prompt } \\
\text { information to tenants about } \\
\text { energy consumption and costs } \\
\text { individual metering requirements }\end{array}$ \\
\hline \multirow{2}{|l}{} \\
\hline
\end{tabular}

In all cases, mandatory performance standards and building codes will induce savings. In order to achieve additional savings, different approaches are needed according to each case. For Case $\mathrm{N}$ the provision of information about the energy performance of end use devices may help buyers to select devices that save energy cost-effectively. Since people in this case are also able to choose their devices, rebates directed toward end users may also be effective.

In Case E, the "efficiency” problem, excess energy consumption occurs because home builders and landlords buy less efficient equipment for occupants since the occupants will incur the energy bills. Stringent building codes and appliance efficiency standards help to obviate much of the problem. In addition, some cities have energy conservation ordinances that require homeowners to install certain energy-saving features when selling their homes. To the extent that 
additional cost-effective savings exist beyond standards and codes, the implementation of home labeling programs and the provision of comparative cost estimates for various efficiency measures using local energy prices will help prospective home buyers and renters take utility costs into account when searching for a new residence. Rebates directed toward end users will not be effective in this case. The rebates should more appropriately be targeted toward builders and landlords.

For Cases B and U, as long as occupants are shielded to some degree from the costs of their energy consumption, it will be difficult to persuade them to make significant conservation efforts. For individually metered units where the landlords pay utility costs, landlords can make it clear to tenants that energy consumption above some baseline level will result in future rent increases. State or local regulations could require landlords in these buildings to provide information to tenants of energy consumption and costs, even if the costs are included in rent. The problem may be less tractable for multiple units served by a master meter. In this case, not only are the tenants shielded from the immediate cost of their energy use because the energy costs of master-metered units are usually included in rent, they are also plagued by a tragedy of the commons. Without individual meters there is no practical way to monitor tenants' energy consumption behavior and enforce cooperation. Laws requiring individual sub-metering will help to ensure that future housing stock is not affected by this problem, but retrofitting buildings with master-metered natural gas may be cost prohibitive. Individual Btu meters for central hot water and steam heating systems are also expensive and may not turn out to be cost-effective for the energy savings they stimulate.

\section{$5 \quad$ Summary and Conclusions}

\subsubsection{Associated Energy Use}

A summary of the total energy use and associated energy use of the residential end-uses examined is shown in

Table 9 Space heating accounts for the largest share (31\%) of primary energy use and from the table it is apparent that a large share of its use is associated with PA problems. Associated energy consumption by water heaters and refrigerators is also significant. Together, the primary energy use associated with PA problems of these three end uses and lighting totals roughly $25.8 \%$ of primary residential energy use. The large shares of their energy associated with PA problems highlights the importance of standards for reducing energy consumption for these and other end uses where purchase decisions will be relatively unresponsive to information-based policies and programs. 
Table 9.Residential Energy Use Associated with the Principal-Agent Problem

\begin{tabular}{|c|c|c|c|c|c|}
\hline & $\begin{array}{c}\text { Refrigera } \\
\text { tors }\end{array}$ & $\begin{array}{c}\text { Water } \\
\text { Heating }\end{array}$ & $\begin{array}{c}\text { Space } \\
\text { Heating }\end{array}$ & Lighting & $\begin{array}{l}\text { Total, } \\
\text { TBtu }\end{array}$ \\
\hline Site Energy by End Use, TBtu (PJ) & $532(562)$ & $1,680(1,650)$ & $4,657(4,465)$ & $343(360)$ & 7,212 \\
\hline $\begin{array}{l}\text { Associated Energy and Shares: } \\
\text { Site Energy, TBtu (PJ) } \\
\text { Share of Site Energy Use } \\
\text { Share of Total Residential Site }^{\text {a }}\end{array}$ & $\begin{array}{r}134(141) \\
25.2 \% \\
1.4 \% \\
\end{array}$ & $\begin{array}{r}1,111(1,076) \\
66.1 \% \\
11.3 \% \\
\end{array}$ & $\begin{array}{r}2,210(2,143) \\
47.5 \% \\
22.4 \% \\
\end{array}$ & $\begin{array}{r}7.8(8.2) \\
2.3 \% \\
0.1 \% \\
\end{array}$ & $\begin{array}{r}3,463 \\
48.0 \% \\
35.1 \% \\
\end{array}$ \\
\hline Primary Energy by End Use, TBtu (PJ) & $1,560(1,156)$ & $2,390(2,320)$ & $5,375(5,313)$ & $1,007(1,002)$ & 10,332 \\
\hline $\begin{array}{l}\text { Associated Energy and Shares: } \\
\text { Primary Energy, TBtu (PJ) } \\
\text { Share of Primary Energy Use } \\
\text { Share of Total Residential Primary b }\end{array}$ & $\begin{array}{r}394(392) \\
25.2 \% \\
2.2 \% \\
\end{array}$ & $\begin{array}{r}1,561(1,519) \\
65.4 \% \\
8.9 \%\end{array}$ & $\begin{array}{r}2,570(2,490) \\
47.8 \% \\
14.6 \%\end{array}$ & $\begin{array}{r}23(23) \\
2.3 \% \\
0.1 \%\end{array}$ & $\begin{array}{r}4,548 \\
44.0 \% \\
25.8 \%\end{array}$ \\
\hline $\begin{array}{l}\text { Estimated Primary Annual Energy } \\
\text { Savings Based on } 2003 \text { Sales }\end{array}$ & $0.48(0.50)$ & $5.89(5.69)$ & N/A & N/A & 6.37 \\
\hline
\end{tabular}

Note: Above results are based on 2001 energy use as applied to 2003 household shares. Annual energy savings are based on 2003 sales.

${ }^{a}$ Residential total site energy - 9,860 trillion Btu (9,840 PJ)

${ }^{\mathrm{b}}$ Residential total primary energy - 17, 600 trillion Btu (17,100 PJ)

\subsubsection{Energy Saved by Removal of the Principal-Agent Problem}

The estimated annual savings from the removal of the PA problem from one year's worth of sales are disproportionately larger for water heaters, 5.9 primary trillion Btu/year, than for refrigerators, 0.5 primary trillion Btu/year. The larger value for water heater savings arises due to several factors. First, the per unit energy consumption of refrigerators is much lower than water heaters. Second, with the introduction of a new, significantly more efficient refrigerator standard in 2001, the 2003 average energy efficiency for refrigerators meant that there was less energy to save than for water heaters. With the introduction of new water heater standards in 2004, a savings calculation based on the average 2004 water heater would also yield a smaller estimate of savings (50\% or less although still higher than refrigerators). Third, a greater share of water heaters sold each year is destined for housing units affected by PA problems (67\% compared to $32 \%)$.

Due to the complexity of calculating the savings potential for space heating and the limited scope of this study, no estimate of its potential was made. For lighting the savings due to eliminating PA barriers would be negligible since information barriers play a much larger role in suppressing sales of efficient bulbs, as evidenced by the low penetration of CFLs in non-affected households. 


\subsubsection{Sensitivity analysis}

Our sensitivity analysis indicates that for refrigerators and water heaters our estimates of the associated energy are quite robust. For space heating, the estimates of associated energy are sensitive to the timeframe used to define "new" units for purposes of determining when original heating equipment is replaced. Additionally, our assumption that new home buyers do not specify their heating-related features may be inflating our estimate of associated energy. With respect to lighting, the most important issue by far is the prevalence of CFL-incompatible downlights.

Estimates of energy savings that may occur in response to removal of PA barriers were generally more sensitive to our assumptions than our estimates of associated energy. For estimates based on new sales, this is largely due to our assumptions about the purchasing patterns between PA affected and non-PA affected households. By default, we have assumed no efficient models are purchased for PA affected households. Thus, a change of a few percent in the assumed penetration rate has a large impact on the results. The stock-wide savings from individually billing the water heating fuel were most sensitive to the assumption that MFR units reporting natural gas included in rent are all accurate. This is due to the greater difference between standard and best-performing natural gas water heaters compared to electric water heaters, the larger number of households with natural gas included, and the assumption that natural gas is the water heating fuel in all households where natural gas is available.

\subsubsection{Conclusions}

Our analysis reveals some important findings. One, price signals alone may have a limited effect on inducing energy conservation in the residential sector because a large share of energy is consumed by end users who either have little or no control over the efficiency of energy-using equipment (Case E) or who are shielded to some extent from the costs of their energy consumption (Cases B and U).

Table 9 highlights the fact that a large share of energy use falls into these categories.

If price signals are not an effective means of eliciting energy conservation in these households, what programs or measures are best tailored to overcome the PA barriers analyzed in this report? In Table 10 we have grouped the shares of each end use's energy consumption by case. The bulk of the energy affected is characterized by Case E. Programs oriented toward the provision of information could overcome these barriers to some extent. Energy Star and HERS ratings for new homes, in addition to appliance labels, may help convince home builders that buyers will pay more attention to efficiency and enable them to pass through costs for better equipment. However, it is difficult to imagine how such a system could be applied cost- 
effectively to the stock of existing and new rental units. Appliance standards and building codes offer one way to address the PA barriers in both rental and occupant-owned housing markets. Information programs may then be used to induce savings beyond minimum standards.

\section{Table 10. Summary of Shares of Site Energy by End Use Affected by Principal-Agent Problems}

\begin{tabular}{|c|c|}
\hline Case N: No P-A Problem & Case E: Efficiency Problem \\
\hline Refs: $72 \%$ & Refs: $25 \%$ \\
WH: $31 \%$ & WH: $59 \%$ \\
SH: $53 \%$ & SH: $40 \%$ \\
\hline Case B: Usage and Efficiency & Case U: Usage Problem \\
Problem & Refs: $3 \%^{\text {a }}$ \\
\hline Refs: $<1 \%$ & WH: $10 \%$ \\
WH: negligible & SH: $8 \%$ \\
SH: negligible & Tist $\mathrm{Cass}$ \\
\hline
\end{tabular}

${ }^{a}$ Refrigerators are an exception since no usage problem exists in Case U, assuming same agent (e.g. landlord) chooses the device and pays for energy.

The households that comprise Case $U$ for a given end use face a different obstacle. These households are either master metered or individually metered, but the landlord pays the utilities nevertheless. We have assumed that landlords have an incentive to invest in reasonably efficient equipment, but this may not be true if landlords believe that they can easily pass through higher energy costs to tenants. Thus, it is likely that standards help to increase efficiency in this case as well. Outreach programs to landlords could help to ensure that tenants are informed that wasteful energy consumption can lead directly to higher rents. However, in units that are master metered, there is a tragedy of the commons problem that will be difficult to overcome without submetering.

Among the end uses we examined, the associated energy use for water heating and space heating accounts for almost 30\% of all residential site energy. These end uses may deserve particular attention for overcoming PA barriers. For example, one study on an energy-efficiency design assistance program found that the program had very little success convincing developers of new MFR units to install gas-fired forced air or hydronic heating rather than electric baseboard systems because developers did not think they could pass the costs through to new tenants (Kelsey and Vance, 2002). This provides evidence of the effect of PA barriers on fuel choice and primary energy efficiency.

\subsubsection{Future Research Needs}

Data on the differences in energy consumption for various end uses by PA case (see Table 1) would be helpful for deriving better estimates of the impact of tenancy status and 
inclusion of utilities in rent on energy consumption. We suggest that RECS provide breakouts of energy consumption by tenancy-status as well as unit type and that future RECS surveys include questions on which fuels are included in rent or other fees. The second key area of research involves studying the degree to which landlords and builders do pass on higher costs for devices and insulation with greater efficiency. We believe that this occurs rarely, but this is based on largely anecdotal evidence. Future studies could also help to elucidate the effectiveness and cost of standards compared to information-oriented programs for Case E households.

Our research highlights the need for several key areas of future research. The key areas include completion of the estimation of energy savings from space heating, the estimation of costs associated with the PA problem for the analyzed end uses, and the prevalence of CFLincompatible downlighting fixtures. The above work could be expanded to include equipment such as set top boxes and other electronic equipment whose energy share and saturation is increasing rapidly and it is either being considered and/or not yet subject to non-price government intervention. Another fruitful set of analysis could focus on the end uses in the commercial buildings sector where parallel data sets are available and on industrial firm failures. 


\section{Acknowledgements}

The authors would like to thank Alan Meier, IEA for initiating the cross-country study and inviting LBNL to participate in the project, Bill Prindle, ACEEE for organizing the workshops and providing general guidance, Jerry Dion and Michael Leifman, DOE, Dave Belzer, PNNL, Alan Sanstad, LBNL, and Rich Brown, LBNL for reviewing the document, providing invaluable insights on the nature of the transactions that are subject to the PA problem, and crosschecking our calculations. We would like to thank Jeff Dowd, DOE, and Mike Shelby and Eric Smith, EPA for supporting the work and reviewing the final document. In addition, we would like to thank colleagues from the six participating countries for their observations at two workshops about the PA problem and approaches to quantifying its impact. 


\section{REFERENCES}

AHAM (Association of Home Appliance Manufacturers), 2003. Fact Book 2003. Washington, DC: AHAM.

Bannock, G, Baxter, R.E., and Davis, E., 1992. The Penguin Dictionary of Economics. London: Penguin Books

Brown R., 1993. Estimates of the Achievable Potential for Electricity Efficiency Improvements in U.S. Residences. Master’s thesis for Energy and Resources Group, University of California, Berkeley

Energy Star, 2006. “Energy Star Qualified Refrigerators and Freezers” (dated June 26, 2006) http://www.energystar.gov/index.cfm?fuseaction=refrig.display_products_excel

GAMA (Gas Appliance Manufacturers’ Association), 2005. "Statistical Highlights: 12/04.” http://www.gamanet.org/gama/stats.nsf/vAttachmentLaunch/90F520265043C29A85256F9D0058 2723/\$FILE/Statistical\%20Highlights\%2012-04.pdf

Itron, 2004. "California Lamp Report 2003.”

http://www.calmac.org/publications/Lighting2003final_07152004.pdf

Jaffe A. and Stavins R, 1994a. The energy efficiency gap: What does it mean? Energy Policy 22 (10): $804-810$

Jaffe, A. and Stavins, R., 1994b. The Energy Paradox and the Diffusion of Conservation Technology. Resource and Energy Economics, 16(2): 91-122

Kelsey, J., and Vance, C., 2002. “Energy Efficiency Design Assistance as Offered Through City Planning, Zoning and Permitting Departments: Experience from the City of Oakland.” in Teaming for Energy Efficiency: Proceedings of the 2002 ACEEE Summer Study on Energy Efficiency in Buildings. Washington, D.C.: American Council for an Energy-Efficient Economy 
KEMA Inc., 2005. “Assessment of the Residential Water Heater Market in the Northwest.” Prepared for Northwest Energy Efficiency Alliance. Oakland, California: KEMA Inc.

Levinson, A., and Niemann, S., 2004. Energy use by apartment tenants when landlords pay for utilities. Resource and Energy Economics 26 (1): 51-75

Mayer, P.W., Towler, E., DeOreo W.B., Caldwell, E., Miller, T., Osann, E.R., Brown, E., Bickel, P.J., and Fisher, S.B., 2004. National Multiple Family Submetering and Allocation Billing

Program Study. U.S. Environmental Protection Agency

http://www.epa.gov/owm/water-efficiency/natmultfamily.htm

NAHB (National Association of Home Builders, Research Center), 2005. Data on refrigerator pre-installations in 2003 housing completions via personal communication from Shelton Cartwright, NAHB Research Center.

Sathaye J. and Bouille D., et al. (2001). Barriers, Opportunities, and Market Potential of Technologies and Practices. Chapter in Climate Change Mitigation, Eds. B. Metz, O. Davidson, and R. Swart. Cambridge University Press for the Intergovernmental Panel on Climate Change

Sathaye, J. and Murtishaw, S., 2004. Market Failures, Consumer Preferences, and Transaction Costs in Energy Efficiency Purchase Decisions.

http://www.energy.ca.gov/2005publications/CEC-500-2005-020/CEC-500-2005-020.PDF

Shama, A., 1983. Energy Conservation in US Buildings: Solving the High Potential/Low Adoption Paradox from a Behavioral Perspective. Energy Policy 11(2): 148-167

U.S. Census Bureau, 2005a. “American Housing Survey National Tables: 2003.” http://www.census.gov/hhes/www/housing/ahs/ahs03/ahs03.html

U.S. Census Bureau, 2005b. “Quarterly Starts and Completions by Purpose and Design.” http://www.census.gov/const/www/quarterly_starts_completions.pdf 
U.S. Census Bureau, 2005c. "Characteristics of New Housing.” http://www.census.gov/const/www/charindex.html

U.S. DOE (Department of Energy), 2000. Chapter 11 of “Technical Support Document: Energy Efficiency Standards for Consumer Products: Residential Water Heaters.” http://www.eere.energy.gov/buildings/appliance_standards/residential/waterheat_0300_r.html

U.S. DOE, 2004. “Department of Energy’s Decision not to Create Energy Star Standard for Residential Water Heaters, Final Letter.”

http://www.energystar.gov/ia/partners/prod_development/new_specs/downloads/water_heaters/ DOE_waterheaterletter_final_1.6.04.pdf

U.S. EIA, 2004a. "Residential Energy Consumption Survey 2001: Consumption and Expenditure Data Tables.” http://www.eia.doe.gov/emeu/recs/recs2001/detailcetbls.html

U.S. EIA, 2004b. Electric Power Annual 2003.

http://www.eia.doe.gov/cneaf/electricity/epa/epa.pdf

U.S. EIA, 2004c. “Square Footage Measurement and Comparisons: Caveat Emptor.” http://www.eia.doe.gov/emeu/recs/sqft-measure.html

U.S. EIA, 2004d. Annual Energy Review 2003. http://tonto.eia.doe.gov/FTPROOT/multifuel/ 038403.pdf

U.S. EIA, 2005. "End-Use Consumption of Electricity 2001.”

http://www.eia.doe.gov/emeu/recs/recs2001/enduse2001/enduse2001.html 


\section{Appendix: Calculation of the Potential Energy Savings from Eliminating the PA Barrier for Refrigerators and Water Heaters Shipped in 2003}

\section{Refrigerators}

Due to the significant differences between the average energy consumption of refrigerators in MFRs and SFRs, we estimated potential energy savings separately by unit type. In order to do this, our basic approach involved several steps.

1. We estimated the number of refrigerators shipped for SFR and MFR units.

2. We estimated the shares of refrigerators destined for PA affected households within each housing unit type.

3. We estimated the difference between the average energy consumption of SFR and MFR Energy Star refrigerators versus non-Energy Star refrigerators.

4. We calculated the share of refrigerators shipped to non-PA affected SFRs and MFRs.

5. We applied the Energy Star shares of the non-PA affected refrigerators to the PA affected refrigerators to derive the expected savings from overcoming the PA barrier.

For the first step, we began with data on total refrigerator shipments. Since we did not have access to a more recent copy of the AHAM Factbook (AHAM, 2003) to determine the number of refrigerators shipped in 2003, we extrapolated from the trend based on 1998 to 2002. This produced an estimate of 9.87 million refrigerators shipped in 2003. Census data on housing completions for 2003 show that 1.39 million SFR units and 0.29 million MFR units were completed in 2003 (U.S. Census Bureau, 2005b). This leaves 8.19 million refrigerators purchased for replacement of refrigerators in existing residences. Splitting these shipments based on the share of SFRs and MFRs in the stock (U.S. Census Bureau, 2005a) yields 6.26 million shipped for SFRs and 1.93 million shipped for MFRs. Adding the replacements to the values for new construction yields a total of 7.65 million refrigerators shipped for SFRs and 2.22 million shipped for MFRs.

For the second step, we apply the shares of new MFRs and SFRs with pre-installed refrigerators ( $85 \%$ and $45 \%$ respectively from NAHB, 2005) to completions to arrive at 0.25 million pre-installed MFR refrigerators and 0.62 million pre-installed SFR refrigerators. Assuming that the replacements are destined for housing unit types based on the shares of unit 
types in the housing stock, 1.34 million refrigerators were purchased for MFR rental units without electricity included and 0.93 million were purchased for rental SFRs without electricity included. This results in 1.59 million MFR refrigerators (71\% of the total for MFRs) and 1.55 million SFR refrigerators (20\% of the total for SFRs) shipped in 2003 for use in residences affected by PA problems, which is $32 \%$ of all refrigerators shipped that year.

For the third step, we used the differences in the shares of Energy Star refrigerators between PA affected and non-PA affected households and the estimated energy consumption of Energy Star and non-Energy Star refrigerator models. This necessitated a few key assumptions. We assume that no refrigerators meant for PA affected households are Energy Star models. Then we estimated the share of refrigerators shipped to non-PA affected households that are Energy Star models. The AHAM Factbook 2003 shows that 25\% of refrigerators shipped in 2002 qualified as Energy Star models, which by definition used at least $10 \%$ less energy than the current applicable federal standard in 2003. ${ }^{14}$ We applied the same percentage to the estimated number of 2003 shipments to arrive at an estimated 2.42 million Energy Star refrigerators shipped. Since no data were available to show what share of those were apartment sized (i.e., 7 to 18 cubic feet of volume), we used the share of available models of apartment-sized Energy Star refrigerators among all models available greater than 7 cubic feet. Apartment-sized refrigerators as of June 2006 constituted a little over 5\% of all models greater than 7 cubic feet (Energy Star, 2006). ${ }^{15}$ Thus the split of Energy Star refrigerators by housing unit type is 2.29 million for SFRs (30\% of the SFR total) and 0.13 million for MFRs (6\% of the MFR total).

To determine the average consumption of Energy Star and non-Energy Star refrigerators by housing unit type, we started with a value given in the Factbook 2003 that the shipmentweighted average energy consumption of all refrigerators in 2002 was $520 \mathrm{kWh}$ /year. RECS 2001 shows that the average MFR refrigerator consumption is $26 \%$ less than the average SFR consumption per refrigerator (corrected for the presence of second refrigerators in SFRs) (U.S. EIA, 2004a). Solving algebraically for the shipment-weighted average by housing unit type given the shares of refrigerators shipped for SFRs and MFRs and the relative difference in energy consumption SFR and MFR models results in a shipment-weighted average SFR consumption of $552 \mathrm{kWh} /$ year and an MFR consumption of $410 \mathrm{kWh} /$ year. Since some Energy Star refrigerators are more than $10 \%$ more efficient than the minimum standard for their category, and some models are slightly less than the standard but not Energy Star models, we assumed that Energy Star models use 12\% less energy than the minimum standard and non-Energy Star models use 2\%

\footnotetext{
${ }^{14}$ Currently Energy Star refrigerators have to be at least 15\% more efficient than the minimum standard.
} 
less energy than the standard. Based on the shares of refrigerators destined for each type of housing unit and the assumed shares of Energy Star models within each type, we estimated that the shipment-weighted minimum standard was $581 \mathrm{kWh} /$ year for SFR refrigerators and 421 $\mathrm{kWh}$ /year for MFR refrigerators. With our assumption that Energy Star models are, on average, 12\% more efficient than the minimum standard, the typical Energy Star SFR refrigerator used $511 \mathrm{kWh}$ /year and Energy Star MFR refrigerators used $370 \mathrm{kWh} /$ year. Since we also assume that the average non-Energy Star refrigerator is $2 \%$ more efficient than the minimum standard, this implies that the average non-Energy Star models consume $569 \mathrm{kWh} /$ year and $412 \mathrm{kWh} / \mathrm{year}$ for SFRs and MFRs respectively.

For step four we divided the number of Energy Star refrigerators shipped by housing unit type by the number of refrigerators shipped to non-PA affected households. Assuming that all Energy Star refrigerators are delivered to non-PA affected homes means that the share of Energy Star refrigerators shipped to non-PA homes is $37.6 \%$ for non-PA SFRs and $20.5 \%$ of non-PA MFRs.

For the final step, we assumed that PA affected purchases of Energy Star refrigerators would climb to the same rate as non-PA affected purchases if the PA problem were removed. Thus, $38 \%$ of the PA affected SFR shipments and $20 \%$ of the affected MFR shipments are multiplied by the differences between the Energy Star and non-Energy Star refrigerators in each class to derive the estimated annual savings of $47.7 \mathrm{GWh} /$ year or $0.16 \mathrm{TBtu}$ of site energy per year.

\section{Water Heaters}

To estimate the potential savings from overcoming the PA barrier for new water heaters a similar approach was used. For waters heaters, we did not perform separate savings calculations by housing unit type. However, for water heaters, the calculations were performed separately by fuel type. The following steps were used to estimate the savings.

1. We started with data on the number of gas and electric water heaters shipped in 2003.

2. We estimated the number of water heaters destined for PA affected households within each fuel type.

3. We used data on the shares of water heaters by various efficiency levels to create weighted average standard and efficient models.

\footnotetext{
${ }^{15}$ The 2003 era lists were not available.
} 
4. We calculated the share of efficient water heaters shipped to non-PA affected SFRs and MFRs.

5. We applied the shares of efficient models among the non-PA affected water heaters to the PA affected water heater shipments to derive the expected savings from overcoming the PA barrier.

For the first step, we used data from the Gas Appliance Manufacturers' Association, which show that 5.12 million gas and 4.43 million electric water heaters were shipped in 2003 (GAMA, 2005). For the second step, we used data on housing completions (U.S. Census, 2005b), the stock of existing rental units (U.S. Census, 2005a), and applied the percentage of water heaters replaced on an emergency basis (KEMA, 2005) to the share of expected replacements for occupant-owned dwellings to arrive at an estimated 3.42 million gas and 2.96 million electric water heaters shipped that were affected by PA problems.

For step three, we used efficiency data from the water heater standard technical support document (U.S. DOE, 2000). Shipment data from this document show that $70 \%$ of gas and $80 \%$ of electric water heaters shipped perform at, or very near, the minimum standard. Using the formula for the 1990 water heater standard, which was not supplanted until 2004, results in a minimum energy factor of 0.544 for gas water heaters (assuming a 40 gallon average capacity) and a minimum energy factor of 0.864 for electric water heaters. The weighted average efficiency improvement of the other $30 \%$ of gas water heaters was about $6.5 \%$. The efficient electric models used $4.4 \%$ less energy than the minimum standard (calculated from U.S. DOE, 2000).

For step four we divided the number of efficient water heaters shipped by fuel type (1.54 million gas and 0.89 million electric) by the number of water heaters shipped to non-PA affected households (1.70 million gas and 1.47 million electric). Assuming that all of the efficient models are delivered to non-PA affected homes means that the share of efficient water heaters shipped to non-PA homes is $90.4 \%$ for gas and $60.3 \%$ for electric.

Finally, applying the non-PA share of efficient models to the water heaters shipped for PA affected households and multiplying the expected annual energy consumption by housing unit and fuel type (U.S. EIA, 2004a) by the percentage of efficiency improvement of efficient models compared to standard models yields 3.9 TBtu of expected annual natural gas savings and 0.7 TBtu of site electricity savings (2.0 TBtu primary). 